\title{
Banks and Development: Jewish Communities in the Italian Renaissance and Current Economic Performance*
}

\author{
Luigi Pascali ${ }^{\dagger}$ \\ Universitat Pompeu Fabra and Barcelona GSE
}

March 23, 2012

\begin{abstract}
Are differences in local banking development long-lasting? Do they affect long-term economic performance? I answer these questions by relying on an historical development that occurred in Italian cities during the 15 th century. A sudden change in the Catholic doctrine had driven the Jews toward money lending. Cities that were hosting Jewish communities developed complex banking institutions for two reasons: first, the Jews were the only people in Italy who were allowed to lend for a profit and, second, the Franciscan reaction to Jewish usury led to the creation of charity lending institutions, the Monti di Pietà, that have survived until today and have become the basis of the Italian banking system. Using Jewish demography in 1500 as an instrument, I provide evidence of (1) an extraordinary persistence in the level of banking development across Italian cities (2) large effects of current local banking development on per-capita income. Additional firm-level analyses suggest that well-functioning local banks exert large effects on aggregate productivity by reallocating resources toward more efficient firms. I exploit the expulsion of the Jews from the Spanish territories in Italy in 1541 to argue that my results are not driven by omitted institutional, cultural and geographical characteristics. In particular, I show that, in Central Italy, the difference in current income between cities that hosted Jewish communities and cities that did not exists only in those regions that were not Spanish territories in the 16th century.
\end{abstract}

JEL: O43, G21, O10

Keywords: Banks, Economic development, Persistence, Jewish demography.

\section{Introduction}

In recent years, an exciting economic literature has emerged that views history as one of the main determinants of current economic development. Beginning with the seminal contributions of Acemoglu et al. (2001), Engerman and Sokoloff (1994) and La-Porta et al. (1997), a significant body of empirical literature has argued that

\footnotetext{
*I would like to thank Alberto Alesina, James Anderson, Benjamin Braude, Susanto Basu, Maristella Botticini, Matteo Cacciatore, Antonio Ciccone, Donald Cox, Scott Fulford, Fabio Ghironi, Francesco Giavazzi, Luigi Guiso, Matteo Iacoviello, Arthur Lewbel, Stelios Michalopoulos, Daniele Paserman, Fabio Schiantarelli, Shannon Seitz, Philip Strahan, Michael Toch, David Weil, Ivo Welch and the partecipants in seminars at Brown University, Boston College, Boston University, Clemson College, UC-Berkeley, Haas Business School, Harvard Business School, EIEF, INSPER, Santa Clara University, Simon Fraser University, Università di Napoli -Federico II, Bank of Italy, Collegio Carlo Alberto, London Business School, Pompeu Fabra University, Getulio Vargas Foundation- Sao Paulo for very helpful comments. Finally, I thank CREMed for generous support, Elisa Giannone for excellent research assistance and Fondazione del Monte for the warm hospitality in their archives.

${ }^{\dagger}$ Ramon Trias Fargas, 25, 08005 Barcelona; phone: (+34)935421190; fax: (+34)935421746; Luigi.Pascali@upf.edu.
} 
historical events, and primarily colonization patterns, have had long-lasting effects on institutions ${ }^{1}$, culture $^{2}$, human capital ${ }^{3}$ and technology ${ }^{4}$ and, through those channels, ultimately on current domestic living conditions. In this paper, I will document another unexplored channel through which history affects current economic development: the creation and evolution of banks.

The first question that this paper attempts to answer is whether local banking development is enduring. This question is central to understanding the remarkable persistence in differences in economic development across countries and regions. Guiso et al. (2008) notes that, among European countries, there is a correlation of 0.56 in per-capita income between the beginning and the end of the last century. Italy is a typical example of persistent regional economic disparities: the literature on the so-called "questione meridionale", the social and economic backwardness of Southern Italy, dates to the end of the nineteenth century. More generally, among Italian regions, there is a correlation of 0.62 in per-capita income between 1891 and $2001^{5}$.

In this paper, I will argue that this fact can be partially explained by longevous local banks. In particular, I document an extraordinary persistence in the disparities of local banking development across Italian municipalities in the last four centuries. For instance, those cities that were hosting Catholic money-lending institutions in the second half of the sixteenth century continue, in modern times, to display a significantly higher number of banks per capita and a greater availability of credit to the private sector. To isolate a causality channel, I first plumb the history of Italian banks and argue that Jewish demography in the early Renaissance exerted a large influence on the development of local credit markets.

My argument rests on the following premises:

(1) Jews arrived in Rome at the time of the Roman Empire as a result of a mass deportation following the defeat of rebels in Judea by the Roman Empire. For commercial reasons, because of temporary expulsions from Rome and especially because they were deported as slaves, the Jewish residents spread from Rome to the rest of Italy. For centuries, they lived primarily in the proletarian sectors, and their religion prevented them from acquiring economic and social prominence in Italy. However, at the end of the fourteenth century, a sudden change in the Catholic doctrine prohibited the Catholics from lending for a profit while still allowing the Jews to do so.

\footnotetext{
${ }^{1}$ Studies on the effects of history on long-lasting institutions are built on an even earlier literature dating back to North and Thomas (1973), North (1981) and North (1990). For a complete review see Nunn (2009).

${ }^{2}$ See for instance, the studies of Alesina and Ferrara (2005) on the effects of cultural and religious fragmentation on long-run growth; Alesina et al. (2011) on the effects of the use of the plough on contemporaneous gender roles; Nunn and Wantchekon (2009) on the effects of slave trade on trust and contemporaneous growth. For Italy, extensive research has studied the origin of social trust and its effect on economic development (see for instance, Banfield (1958), Putnam (1993) , Guiso et al. (2008) and Durante $(2009))$.

${ }^{3}$ See Botticini and Eckstein (2007) on the effects of changing religious norms on literacy.

${ }^{4}$ Spolaore and Wacziarg (2009) documents the effects of genetic distance on technology diffusion and development. Comin et al. (2010) documents the importance of early technology adoption on current economic performance.

${ }^{5}$ This result is based on the estimates of Felice (2005) on the value added produced in Italian regions in 1891.
} 
(2) Cities that hosted a Jewish community developed complex credit markets. This happened for two reasons. The first was that Jewish communities specialized in the money-lending business. The second was that the Franciscan propaganda against usury, which was particularly ferocious during the fifteenth century, led to the creation of charitable loan banks, called "Monti di Pietà", that were intended to drive the Jews out of the local financial market. The "Monti di Pietà" were created in those cities were the Jewish minority was most influential.

(3) While Jewish pawnshops disappeared, the Monti survived to the present day and gave rise to a significant portion of the current Italian banks.

Consider, for example, the cities of Ivrea and Chivasso. These two cities have a similar demographic history ${ }^{6}$ and shared the same rulers for at least eight centuries ${ }^{7}$. Today, they share the same legislators and the same courts because they both belong to the province of Turin. However, Ivrea hosted a Jewish community in 1500 (tourists can still visit an ancient Jewish cemetery and a synagogue), while Chivasso did not. In 1591, a Monte di Pietà was created in Ivrea; its constitution act was motivated by the need to protect the Catholic masses from Jewish usury. Although the Jewish community disappeared at least a century ago, the Monte operated until 1984 as the primary lending institution in the city. Still today Ivrea dominates Chivasso in terms of private credit-to-GDP ratio (98 percent versus 42 percent) and number of bank branches per resident (0.001 versus 0.0006$)$. To conduct the analysis in a more systematic manner, I identify the Italian cities that had at least five thousand citizens before the Italian unification in 1861 (excluding the islands). For those cities, I reconstruct the approximate size of the Jewish population in 1500 and I collect data on the local banks that they hosted beginning in 1470 (the year of incorporation of the first Monte) until 1670. Then, I document the persistence of these local banks until the present day using the Jewish demography in 1500 as an exogenous source of variation.

The exclusion restriction implied by my instrumental variable regression is that: (1) conditional on the controls included in the regression, the Jewish demography of five centuries ago has had no effect on banks today other than through its effect on the local credit markets in the Renaissance; (2) there are no unobservables systematically correlated with Jewish demography of five centuries ago and current local banks. As we will see more in details in the next section, the Jews in Italy were a very small minority, segregated from the rest of the Italian population and living almost exclusively from the revenues of the money-lending activities. Still, if there is a location advantage (not captured by eventual controls) that led the Jews to settle in a particular city and

\footnotetext{
${ }^{6}$ According to Malanima, they had less than 5 thousands residents until the early 19 th century. According to the first Italian census, in 1861 Ivrea had around 6 thousands residents and Chivasso few hundreds less. Today, Ivrea has 23,714 residents while Chivasso 23,649 residents.

${ }^{7}$ In the 13th century they are both under the domain of the emperor Frederick II who assigned them to the marques of Monferrato. In the 14th century, they passed under the House of Savoy where they remain until the unification of Italy.
} 
that, at the same time, affects current local banking development, then my instrument will be inappropriate. In fact, it is very likely that some particular geographic, cultural, institutional and economic characteristics may have attracted the Jews to select certain cities rather than others in 1500 . To exclude the possibility that these characteristics may have any direct effect on current local banks, I use a difference-in-difference approach based on an historical counterfactual. Between 1503 and 1541, Jews were fully expelled from the Italian areas under the Spanish crown, to which they would not be allowed to return for three centuries. This event is exogenous with respect to the Italian social and economic situation of that period. It was, in fact, the result of the attitude of the Spanish crown toward the Jews: the edict was promulgated in Spain in 1493; in 1503 a large part of Italy fell for dynastic reasons under the Spanish crown and the edict of expulsion was applied here as well. I limit my analysis to Central Italy and I document that, once controlling for a set of observed geographical characteristics, in the once-Spanish areas there is no within-province difference in the level of current financial and economic development between those municipalities that previously hosted Jewish communities and those that did not. There are large differences within a province, instead, in those areas where Jews were not banned from: here cities that formerly hosted Jewish communities currently have larger credit-to-GDP ratios and GDP per capita. I interpret this result as an indication that there are no unobservables that affect both the presence of Jewish communities in 1500 and the current local banking and economic development.

Having established the validity of my instrument, I can use it to estimate the persistence of credit institutions. The results are surprising: for instance, having hosted a Monte di Pietà in the Renaissance gives rise today to an increase in credit availability to the private sector (in percentage of GDP) in the order of at least 80 percent and an increase in branch density of 24 percent.

The second central question that this paper attempts to answer is whether banks affect long-term economic performance. On this topic, the economic theory is divided. A large body of literature dating back to Schumpeter emphasizes the positive influence of the development of a country's financial sector on the level and the rate of growth of its per-capita income. The main argument is that financial intermediaries reduce the cost of acquiring information and allow for the better assessment, selection and monitoring of investment projects. For example, in Greenwood and Jovanovic (1989), the ability of financial intermediaries to improve information collection results in an increase in the efficiency of resource allocation and, hence, in economic performance ${ }^{8}$. However, according to certain theoretical contributions (for example, Bencivenga and Smith (1991); King and Levine (1993b)), an improvement in the reallocation of resources that results in an increase in the return to savings may actually depress saving rates and compromise future economic growth. Because the theoretical literature is divided, it remains the task of the empirical literature to shed light on the effect of finance on

\footnotetext{
${ }^{8}$ See also Diamond (1996).
} 
development. In the 1990s, beginning with studies by King and Levine (1993a, 1993b), a new body of empirical evidence began to indicate a positive relationship between the level of development achieved by the banking system and economic performance, both at the national and the regional level. Italy represents a favorable "laboratory" for these empirical studies ${ }^{9}$ for two reasons. First, focusing on Italy allows researchers to isolate the role of banks in fostering economic performance. The Italian financial system can be characterized as bankbased. The capitalization of the Italian stock market is low compared to that of most of the other developed countries, and Italian firms have traditionally used debt rather than equity to finance their activities. Therefore, banking development is likely to be particularly important for Italian firms. Second, there is considerable spatial diversity in the degree of banking development. Until 1999, the competition among Italian banks was dampened by restrictions on lending and branching across geographical areas. This led to the development of fundamental differences between the local credit markets of Italian cities. A possible objection could be that the local conditions of the credit market become irrelevant as long as individuals and firms can tap markets other than the local one. There is a growing body of literature, however, documenting that distance affects the provision of funds, especially for small firms (Petersen and Rajan (2002); Bofondi and Gobbi (2004); Lerner (1995)). Moreover, the fact that distance is an important barrier to lending is consistent with the views of bankers. Guiso et al. (2004) report that "the president of the Italian Association of Bankers (ABI) declared in a conference that the banker's rule of thumb is to never lend to a client located more than three miles from his office."

Although a large amount of empirical literature has documented a strong correlation between banks and development, assessing the direction of causality has proven to be a difficult task ${ }^{10}$. There is little agreement on

\footnotetext{
${ }^{9}$ Lucchetti et al. (2001) examine how the efficiency of local banks affects regional economic development. Angelini and Cetorelli (2003) study the effects of regulatory reforms on bank mark-ups. Bonaccorsi di Patti and Dell'Ariccia (2004) focus on firm creation. Guiso et al. (2004) present evidence of the effect of local financial development on a wide set of outcomes, such as business formation, firm entry and growth. Guiso et al. (2006) study the effect of banking regulation on the cost and access to credit. Alessandrini et al. (2006) present evidence that higher branch density reduces the probability of firms of being financially constrained. Benfratello et al. (2008) concentrate on the effects of branch density on the probability that firms engage in R\&D.

${ }^{10}$ Four different approaches have been utilized in this literature.

In a successful contribution, King and Levine (1993a) show that on a cross-country basis, the predetermined component of financial development is a good predictor of growth over the following 10 to 30 years. However, skeptics offer two arguments against this methodology for analyzing causality. First, there may be some omitted variable, such as the propensity of households to save, driving both financial development and economic development. Second, there may be a reverse-causality problem because the usual measures of financial development (capitalization of the stock market and availability of credit to the private sector) may respond to expectation of future growth.

The second approach aims to rule out omitted country-level factors by focusing on interaction effects rather than on the primary effects of financial development. On a cross-country basis, using industry-level data, Rajan and Zingales (1998) test the idea that financial development should disproportionately assist industries that are relatively more dependent on external finance for their growth. As a proxy for a certain industry's external need for financing, the authors use data on the difference between investments and cash flow in the analogous industry in the US. The main problem with this approach is that the results are hard to interpret without making the following assumptions: all countries share the same technologies and perform the same tasks within each industry and capital markets in the US are perfect.

The third approach focuses on the time-series dimension and studies the effect of one-time exogenous financial liberalization. For example, at the US state level, Jayaratne and Strahan (1996) find that economic growth increases in states that relax intrastate bank branching restrictions. However, according Fry (1995), the simultaneity of reforms appears binding for this type of study: "Most clear-cut cases of financial liberalization were accompanied by other economic reforms (such as fiscal, international trade
} 
what determines banking institutions, making it difficult to isolate exogenous sources of variation and estimate their effects on performance.

Using Jewish demography in 1500 as an instrument, I find that an increase in the current credit availability of 1 percent increases GDP per capita in Italian municipalities by at least 0.18 percent. The effect of branch density is even stronger: an increase in the ratio of bank branches to total residents of 1 percent increases per-capita GDP by at least 0.7 percent. In other words, if a bank "fell from the sky" in a city characterized by the average branch density and one hundred thousand residents, we expect local GDP per capita to increase by 2.8 percent. These estimates support the view that credit institutions have strong positive effects on economic development. Interestingly, according to my estimates, at least one-third of the gap in the current credit availability between Northern and Southern Italy can be attributed to the expulsion of the Jews from the Aragon kingdom. This finding implies that at least 12 percent of the north-south gap in per-capita GDP is attributable to the current lower credit availability for which the expulsion was responsible.

In the last part of the paper, I illuminate a particular channel through which the improvement of credit institutions affects economic development. The so-called "Shumpeterian view" in the literature on finance and growth is based on the idea that banking institutions affect economic performance through their ability to foster aggregate productivity (e.g., the total output produced by the economy for a given set of inputs) rather than capital accumulation. My results validate this view. An increase in credit availability of 1 percent increases aggregate productivity by at least 0.03 percent ( 0.2 percent for branch density). Moreover, I show that the effects of banks on aggregate productivity are realized through the reallocation of resources towards more productive firms rather than through a boost in the average productivity of firms. This finding appears to validate theories that emphasize the importance of the role of the banks in exploiting ex-ante information on investment opportunities to select the most promising ones.

This paper is organized as follows. Section 2 presents historical background information on the Italian Jewish communities and the origin of Italian banks. Section 3 documents the persistence of the relative levels and foreign exchange reforms). In such cases it is virtually impossible to isolate the effects of financial components of the reform package".

The final approach that has been widely used in the literature is the instrumental variable approach. Many authors have used GMM estimators developed for panel data where the instruments come from lagged values of a financial development proxy. Levine et al. (2000) use data on a panel of 77 countries over the period 1960-1995. The primary advantage of this methodology is that it controls for cross-sectional fixed effects. However, the procedure is data-intensive, and researchers cannot normally count on long time series. As Levine (2005) notes: "Levine et al. (2000) employ data averaged over a five-year period, yet models we are using to interpret data are typically models of steady state growth. To the extent that five years do not adequately proxy for long-run relationship, the panel methods may imprecisely asses the finance growth link". In order to overcome this problem, researchers have searched for "external" instruments that can explain cross-sectional differences in financial development without requiring long time series of data. Levine (1998), Levine (1999) and Levine et al. (2000) use the La-Porta et al. (1998) measures of the legal origin of the country as instruments for current financial development. This type of analysis has three important drawbacks. First, it is difficult to exclude the possibility that these instruments have affected not only financial institutions but also other institutions. For example, the legal origin of the country affects the local contractual institutions (see La Porta et al, 2001). Second, it is difficult to rule out missing geomorphological variables that could drive both instrumental and instrumented variables. Third, these studies are usually based on a small number of observations. 
of local banking development across Italian municipalities in the last five centuries. Sections 4 and 5 examine the effects of current banks on per-capita GDP and aggregate productivity in Italian municipalities. Some concluding remarks close the paper.

\section{The Jews in Italy and the Rise of the Monti di Pietà}

Jews were already present in Italy in the second century B.C.E. ${ }^{11}$ The first large communities were the result of mass deportations following the Jewish struggle and defeat in Judea at the hand of the Roman Empire ${ }^{12}$. Bonfil (1991) describes the Jewish communities' role in the Roman society accordingly:

"The fact that the Jews in Italy were of petty bourgeois or even servile origin and that they were not infrequently suspected of opposing Roman policy abroad prevented individual Jews from attaining prominence in economic or social life. [..] They engaged in humble occupations and lived in the proletarian sections. Cultural standards were not high, although there were painters, actors, and poets."

It has been estimated that approximately fifty thousand Jews were living in Italy during the first century. For commercial reasons, because of temporary expulsions from Rome and especially because they were deported as slaves, the Jews spread from Rome to the rest of Italy. Whenever possible, they established themselves in more cosmopolitan cities where the local population was more tolerant of their religious convictions and customs. For these reasons, we find Jewish communities concentrated in cities with important ports or where commerce was a prominent activity (Milano (1963), p. 29).

Even after the fall of the Roman Empire, the strong opposition of the Christian Church confined the Jews to the margins of Italian society. According to Bonfil, until the end of the 13th century, Jews remained a group of petty bourgeoisie, primarily artisans (especially dyers and silk weavers) and small merchants. Typically, they owned houses in towns, but occasionally, some Jews also engaged in farming ${ }^{13}$.

This situation dramatically changed in the 14th century. During this period, Jews in Italy engaged in a new sphere of economic activity as money-lenders. There were three main motives that drove the Jews towards

\footnotetext{
${ }^{11}$ The first evidence of Jewish presence in Italy dates back to 168 B.C.E. A Jewish general, Maccabees was leading the struggle to free Palestine from the Syrian domination and sent an embassy to Rome asking for military support.

${ }^{12}$ The first large wave of Jewish prisoners arrived in Italy in 61 B.C.E. after Pompey and the Roman legions had submitted Judea under the Roman Empire and conquered Jerusalem. In 66 C.E., Judea rebelled against the invaders: the war lasted four years and ended up with the complete defeat of the Jews. Again, a large portion of the Jewish prisoners was brought to Italy. According to later sources, 1500 arrived in Rome alone and 5000 in Apulia. The last mass deportation of Jewish prisoners in Italy dates back to 134, when the Jewish struggle against the Romans ended up with the wholesale destruction of Jerusalem and more than one thousand of other Jewish towns.

${ }^{13}$ In the middle of the thirteenth century, Saint Thomas Aquinas wrote that, unlike in other countries, Jews in Italy earned their livelihood through their own work and not through money-lending.
} 
lending. First, during the Middle Ages, the Catholic Church, through several Ecclesiastical Councils, had banned the practice of lending to earn a profit ${ }^{14}$. This prohibition, which had previously been limited to the Catholic clergy, was extended to the Catholic laity. On the other hand, the Lateran Council in 1215, having forbidden Jews from lending for high and immoderate interest rates, silently allowed them to lend in exchange for normal interest. Second, between 1260 and 1340, the Italian peninsula experienced a strong expansion of merchant and craft guilds (Morelli (2008)). These organizations acquired full control of the primary economic activities in the largest Italian cities. Because membership required adherence to Catholicism, a large number of Jews were forced to leave their traditional occupations. Moreover, Jews could not continue their farming activities because they were not allowed to own land in a majority of the Italian states. Third, some Jews in Central Italy who had engaged in trade during the Middle Ages had accumulated sizable wealth and had both the capital and the expertise to become money-lenders.

These three factors drove the Jews en masse toward money-lending. By the beginning of the 15th century, the geographic expansion of the loan business by the Jews was complete and had become a general economic phenomenon in all parts of Italy. According to Shulvass (1973), Italian Jews in this period primarily derived their livelihood from usury, pawnshops and lending ${ }^{15}$. This led to the accumulation of small fortunes for several Jewish bankers. A large number of Jews adopted the manners of the gentile upper class, with a taste for the letters and the arts; indeed, this period is remembered as one of unprecedented prosperity of the Italian Jewry. These achievements, however, were undermined by two factors.

The first was the attitude of the Spanish Aragon crown toward its Jewish subjects. In March 1492, the Aragon crown promulgated an edict of expulsion of the Jews from its territories. At that time, Sicily and Sardinia were under the Aragon rule, and thus the edict applied there as well. Then, in 1503 the Kingdom of Naples (which included all of Southern Italy, the region of Abruzzi and some cities close to Rome) came under the Aragon crown, and the expulsion of the Jews from these territories was ordered. The opposition to the edict by both the Christian masses and the local aristocracy led to certain exceptions. In particular, approximately 200 wealthy families were formally permitted to remain. However, in 1541, these exceptions were abrogated,

\footnotetext{
${ }^{14}$ The Christian prohibition to lend for a profit tracks its origin in the ancient times and is inspired by two principles. First, the Aristotelian maxim "Pecunia pecuniam parere non potest (money cannot beget money)" excluded the possibility that investing for future profits could be beneficial for the society. Second, lending for a profit was considered at odds with the principle "Mutuum date nihil inde sperantes (give without hoping to receive anything in return)", enunciated in the Gospel according to Saint Lucas.

${ }^{15}$ In 1320, Kalonymos ben Kalonymos (1286-1328 A.D.), a Spanish Jewish philosopher, wrote in his Maseket Purim: "no usurious loans are to take place on Purim that is in the land of Israel, but it is permitted in Babylonia and in Greek Italy [..]. Jews of Babylonia and Italy have nothing else but usury upon which to rely [for their support]". Two centuries later, Jehiel Nisim da Pisa (1507-1574 A.D.), a rich Italian Jewish banker, also attested that "in these lands [Italy] more than everywhere else in the entire Diaspora has the custom of lending to non-Jew become widespread". Famous rabbis were also moneylenders and, according to Sonne (1948), most of the North Italian rabbis were bankers even at a time when they functioned as heads of rabbinical schools. Leon da Modena (1638) charged that "in our generation all interest lenders are regarded honorable and not only are they not ineligible to testify and to judge, it is quite the reverse, namely, their word is as reliable as a hundred of witnesses, they are our leaders and judges".
} 
and the law excluding Jews from the kingdom remained in force for over three centuries.

Meanwhile, other Italian states experienced increasing opposition towards Jewish loan-banking from the Christian population. According to Shulvass,

"The economic depression of the masses caused by endless wars waged throughout all of Italy, contrasted with a rise in the living standard of Jewish pawnbrokers, aroused strong anti-Jewish feelings. The movement was led by the Franciscans, who during this period had a number of outstanding itinerant preachers with tremendous influence upon the masses. [..] They believed that the abolition of the Jewish loan business would heal all social ills. The masses also believed that the loan business was ruining the country."

With the explicit intention of keeping Christians in need of loans away from Jewish money-lenders, Franciscan leaders such as Bernardino da Siena, Giacomo della Marca, Giovanni da Capistrano, and Bernardino da Feltre laid the foundations for the "Monti di Pietà", lending institutions sponsored by wealthy Christians that would extend credit on a non-profit basis.

The creation of a Monte di Pietà followed a usual scheme, which is well-described by Attilio Milano (1963, pp. 74). A Franciscan preacher would arrive in town and offer several sermons to the largest audience possible, proclaiming that the current misfortune of the place was a divine retribution against the persistence of Jewish usury; in order to appease God's wrath, usury should be overcome ${ }^{16}$. An expiatory procession would follow, during which each member of the community was supposed to contribute to the formation of the initial capital of the Monte, normally in exchange for the plenary indulgence. Finally, the Franciscan preacher would assist the local authorities in writing the statute of the Monte ${ }^{17}$.

Several anecdotal stories regarding the creation of the Monti have survived to the present day. For example, according to his biographer, in 1470 Bernardino da Feltre arrived in L'Aquila, a town in Abruzzi, and offered 82 sermons instigating the inhabitants to create a Monte and to kill the Jewish minority ${ }^{18}$. Two weeks later, several processions and turbulent manifestations of the population led the city council to authorize the creation

\footnotetext{
${ }^{16}$ One of the main Franciscan preacher of that time, Bernardino da Siena, used to depict Jewish lenders as bloodsuckers. In his sermon 43 on usury he says: "It is usually the case that when wealth and money are concentrated into fewer and fewer hands and purses, it is a sign of the deteriorating state of the city and the land. This is similar to when the natural warmth of the body abandons the extremities and concentrates only in the heart and the internal organs; this is seen as the clearest indication that life is slipping way and that the person is soon to die. And if this concentration of wealth in the hands of the few is dangerous to the health of the city, it is even more dangerous when this wealth and money is concentrated and gathered into the hands of the Jews. For in that case, the natural warmth of the city - for this is what its wealth represents - is not flowing back to the heart to give it assistance but instead rushes to an abscess in a deadly hemorrhage, since all Jews, especially those who are moneylenders, are the chief enemies of all Christians."

${ }^{17}$ Figure 3 reproduces a painting of Sebald Popp, "The sermon of the pious Giovanni da Capestrano in Norimberga". The painting dates 1493 and it describes a typical Franciscan predication. You can distinguish a Franciscan preacher giving a sermon, the women piling up their best clothes and jewels in front of the preacher (the mount of piety was originally referred to a pile of objects collected for being redistributed to the poor people) and, on the upper left of the representation, you can distinguish a Jew being arrested by the local authorities.

18 "fin che gl'ebrei non fosser da gl'Aquilani tagliati a pezzi" (until the Jews would have been cut in pieces by the inhabitants).
} 
of a Monte di Pietà. In its statute, we can still read that the Monte was created with the with the mandate to "refrenare la insatiabele voragine della usura de Judey, la quale devora et consume li beni temporali dell'omini et persone de essa magnifica cita dell'Aquila e so contato" (to stop the insatiable bottomless chasm of Jewish usury, which devours and consumes all the goods owned by the people of the magnificent city of L'Aquila and its county). Several days after the establishment of the Monte, the Jews were expelled from the city (although they would be invited to come back two years later).

The connection between the creation of the Monte di Pietà and the anti-Jewish propaganda left traces in the statute of the great majority of the Monti di Pietà that were created before the beginning of the 18th century $^{19}$.

Many papers have been written by historians and economists on the relationship between Jewish demography and the rise of the Monti di Pietà in the Italian Renaissance ${ }^{20}$. The mainstream historical perspective can be summed up by the words of Segre (1978):

"The mounts rise where there are Jewish bankers and their reason of being and their fuel is the opposition to the Jewish bankers and, sometimes their destruction under an overwhelming public pressure".

In the words of Menning (1993):

"As brokers of small loans against pawns, Italian Monti di Pietà were expected not only to replace Jewish moneylenders but also to set up the conditions in which all Jews could be expelled."

Between 1470 and 1570, the Franciscan preachers created more than two hundred Monti di Pietà in Central and Northern Italy. However, the lack of a firm business base undermined their stability. They were continuously dependent on charity to finance their operations, and the lack of any profit motive made them particularly inefficient. The presence of a Jewish community in the city provided three different means of solving the problem. First, the Franciscans continued to use the specter of Jewish usury to promote frequent processions, where the forgiveness of multiple sins was exchanged for donations to the Monte. Second, the Jews were frequently forced to pay a tax to the local Monte or to deposit some of the revenues of their money-lending activities. Finally, in other cases, they provided the initial expertise to set up the Monti.

\footnotetext{
${ }^{19}$ For example, you can find references to the Jewish usury in the constitution statutes of the following lending institutions: Monte di Pietà di Viterbo (1472): "una losca nidiata di ebrei" (sinister brood of Jews); Monte di Pietà di Parma (1491): "ad evitare le voragine de le usure de zudei per subventione dei poveri christiani" (to avoid the bottomless chasm of Jewish usury by subsidizing the poor people); Monte di Pietà di Parma (1491): "alla iattatura delle usure et massime delli zudi" (to the damnation of usury and, especially, the Jewish one); Monte di Pietà di Rieti (1489): "succatori del sangue de li cristiani" (suckers of Christian blood); Monte di Pietà di Cuneo (1557): "voragine dell'usura di ebrei"; Monte di Pietà di Casale (1557):" ai giudei che devorano il sangue de poveri" (to the Jews that devour the poor's blood); Monte di Pietà di Savigliano (1602):"ingorda tirannia degli usurai ebrei" (gluttonous tyranny of Jewish usurers).

${ }^{20}$ An excellent collection of studies on the relationship between Jewish demography and the rise of the Monti di Pieta' is offered by Montanari (1999). See also Angiolini (1978).
} 
This led Attilio Milano (1963, pp. 165) to conclude that "the co-existence of Monti di Pietà and Jewish pawn banks was not only possible but also necessary" and, for this reason, the Jewish money-lenders who had been expelled after the creation of the Monti were, in most cases, invited to come back.

The Monti di Pietà, which were founded as charity institutions, evolved particular features typical of modern banks in the late sixteenth century. In fact, in 1515, Pope Leone X, allowed them to charge interest on their loans; in 1560, Pope Pius IV authorized them to accept deposits from privates; and finally, in 1569, Pope Pius V allowed them to remunerate these deposits. However, until the late seventeenth century, the Monti continued to primarily rely on charity and donations to finance their growth, and their endowment remained relatively low compared to Jewish pawnshops. The Monti were allowed to receive deposits and make loans only to residents; these loans were limited in size (they would not exceed the average monthly wage of a peasant) and duration (6 months or 1 year), and their use was bound by rigid moral rules. Moreover, in periods of general hardship, it was difficult for the Monti to raise sufficient funds given that all of their donors and depositors lived in the same town. On the other hand, Jewish pawnshops could lend much larger sums for longer periods. Furthermore, through a network of family ties, social relationships and economic partnerships, they were able to provide access to external sources of credit ${ }^{21}$.

It was only between the 17th and the 18th century that the Monti di Pietà were able to expand their range of activities from consumption credit to production credit (Montanari (1999), De Maddalena (1975)). While the Italian Jewish money-lending industry experienced a steady decline and eventually disappeared, the Monti were surprisingly resistant over time. By the end of the 19th century, approximately 300 Monti were operating in Italy (Pagliazzi and Nicosia (1968)).

One obvious question is whether those cities that could not count on Jewish pawnshops or Monti di Pietà developed alternative ways to provide credit that could avoid the interest ban. The answer is yes. First of all, inter-household credit was very popular. Since no credit contract could make references to an associated interest, the actual payment of the interest was dependent on the good faith of the parties. The legal risk involved with these types of transactions led to the development of more complex contractual form where the loan component was hidden or not easily identifiable. The most popular by far was the so-called "Contratto alla Voce". Practically, during the planting season a creditor would purchase and pay in advance the current price for part of the upcoming harvest that the debtor had the obligation to re-purchase immediately after the harvest at the new current price. The interest was hidden in the price-difference of farm products between the planting season and the harvest (Placanica (1982)).

\footnotetext{
${ }^{21}$ An interesting discussion on the complementarity between Jewish money lenders and Monti di Pietà can be found in Botticini (2000). See also Montanari (1999) (p. 10).
} 
So, this was the situation of the Italian credit institutions in 1860 , immediately after a myriads of little states and independent cities were unified in the Italian Kingdom: local Monti di Pietà, with centuries of banking experience in those cities that used to host Jewish communities in the early Renaissance, and a mix of ancient complex contracts aiming at hiding the interest payments in the other cities. Immediately, after the Italian unification the Italian banking system was deeply re-organized. The Monti lost some of their banking prerogatives, while a new type of banks, the Casse di Risparmio began to dominate the local credit markets. The great majority of the Casse born either as a commercial appendix of the local Monte or as aggregation of several of them (Zamagni (2005); Racine (2004)), they shared with the Monti the non-profit nature and the institutional mission to fight against usury but they could benefit from more relaxed regulatory legislation. In particular, the Casse di Risparmio were allowed to collect deposits indiscriminately from the private sector and to invest them on economic basis rather than on charity ones. Some decades later, with the banking reform in 1929, the regulatory legislation for the largest Monti di Pietà was assimilated into the legislation governing the Casse di Risparmio and the Monti forfeited their original charitable mission. The last relevant legislative reform occurred in 1992 (but was implemented only in 1999). Both the Monti di Pietà and the Casse di Risparmio lost their non-profit status, and they were transformed into joint-stock companies; meanwhile their ownership was transferred to the Fondazioni which have continued to operate as non-profit organizations until today.

\section{Data Description}

This paper employs three sets of data: the first two include historical and current data, respectively, on Italian municipalities, while the third one includes detailed characteristics of Italian firms.

The first set of data contains information on demography and local credit markets in the Renaissance in Italy (islands excluded). Historical data on the location of the Monte di Pietà, the Jewish communities and the Jewish pawnshops between 1450 and 1650 come from miscellaneous secondary sources. The historical urban population data come from Malanima (1998). Federico Malanima compiled a dataset with urban population estimates for over 500 Italian cities on a centennial basis over the period 1300-1861, relying heavily on the seminal work on Italian population history by Beloch (1963). The sample comprises all of the Italian cities with an estimated average population of at least five thousand people in the year of the Italian unification (1861). Data on the location of the Monte di Pietà and the Jewish pawnshops in the first century of their existence (1470-1570) comes from miscellanous sources. Table 1a reports the summary statistics for this set of historical data. The sample comprises 360 cities, of which nearly half previously hosted a Jewish community. Of the 173 Jewish communities in 1500, more than half were small (101), approximately a third were mediumsized (47) and the rest were large (25). Nearly a third of the Italian cities in the sample had a Monte di Pietà 
or a Jewish pawnshop operating in their territory. Regarding the data on urban population, it is interesting to notice the extraordinary drop in urban population between 1300 and 1400 caused by the epidemics of the plague.

The second set of data contains current information on Italian municipalities (the data refer to the years 2002-2003). The geomorphological data come from the Italian Geographical Institute De Agostini. Statistics on population and levels of education come from the Italian National Statistical Institute (ISTAT). The same source provides value-added data. These are available not at the city level but rather at the level of the "local labor system" (LLS). This unit is defined on the basis of the Population Census data and is composed of a set of contiguous municipalities with a high degree of self-containment of daily commuter traffic and similar economic and geographic characteristics. There are a total of 854 LLSs in Italy, and all cities in my sample are located in distinct LLSs. In the rest of my analysis, I will assume that the per-capita GDP of each city is the same as that of the LLS where the city is located. Financial data on branch density and private credit come from the Bank of Italy. Table $1 \mathrm{~b}$ reports summary statistics for these city-level data. It is interesting to notice the large variation in the level of economic development across Italian cities. The richest city has a GDP per capita that is more than eight times that of the poorest city. Looking at financial data, the private credit to GDP ratio has a surprisingly large mean (0.71) and standard deviation (0.57). For example, using a sample of 75 countries and a similarly constructed measure of private credit to GDP ratio, Levine, Loayza and Beck (2000) report a mean of 0.4 and a standard deviation of 0.29. This reinforces the idea that Italy has a bank-based financial system and features a significant degree of variation in the level of financial development across cities.

The third dataset contains current information about Italian firms. The main source of information is Amadeus, a comprehensive firm-level pan-European database developed by Bureau Van Dijk. For every firm, it provides data on the industry in which the firm operates (at the 4-digit NACE level), the location, the year of incorporation, the ownership structure and the number of employees, in addition to the complete balance sheets and the profit and loss accounts. The data set includes both publicly traded and non-traded companies and accounts for nearly 90 percent of the sales reported in the national accounting data. In order to deflate firms' sales, materials, intermediates and capital, I have merged this dataset with an industry-level dataset that comprises output and input prices for industries at roughly the 2-digit level of aggregation coming from the EU-KLEMS project. Table 1c reports summary statistics for firms' deflated quantities.

\section{Long-Term Persistency}

The evolution of the Italian banking system can be documented by the following system of equations: 


$$
\begin{gathered}
J F_{i}=\alpha_{1} J_{i}^{1500}+X_{i}^{\prime} \beta_{1}+v_{1, i} \\
M P_{i}=\alpha_{2} J F_{i}+X_{i}^{\prime} \beta_{2}+v_{2, i} \\
\log F_{i}=\alpha_{3} M P_{i}+X_{i}^{\prime} \beta_{3}+v_{3, i}
\end{gathered}
$$

where $J_{i}^{1500}$ is a dummy variable that identifies cities that previously hosted a Jewish community in 1500 , while $J F_{i}$ and $M P_{i}$ identify those cities that were hosting respectively Jewish pawnshops and Catholic Monti di Pietà in the following century; $F_{i}$ measures the current level of local banking development and $X^{\prime}$ is a vector of covariates that affect all variables.

The first equation captures the fact that, during the Renaissance, the Jews were the only people in Italy allowed to charge interest, and that they derived their livelihood almost exclusively from the revenues of their moneylending activities. Thus, the presence of a Jewish community was generally associated with the presence of several Jewish pawnshops in the local credit markets.

The second equation reflects the mainstream historical perspective on the rise of the Monti di Pietà. They were created with the explicit scope of counteracting the influence of Jewish money-lending. The presence of a Jewish community not only spurred the creation of the Monte di Pietà, but it was also necessary for the survival of the Monte. The Monti were continuously dependent on charity and donations: waving the specter of the Jewish usury was an effective way of raising funds. In the first century of their activity, 229 Monti di Pietà opened in Italy, and the great majority of them were located in cities that hosted Jewish communities; only 17 opened in the Spanish territories from which the Jewish population had been expelled (where nearly 40 percent of the Italian urban population was concentrated).

Finally, the third equation captures the fact that, where the expansion of the Monti di Pietà could benefit from the Jewish presence, the Monti were able to survive until the present day, thus forming the foundation of the contemporary Italian banking system. In 1995, the largest Italian banks by number of branches in Southern, Central and Northern Italy were Banco di Napoli, Banca di Roma and San Paolo, respectively. Banco di Napoli was funded through the merger of eight Catholic institutions that were established in Naples between 1539 and 
$1640^{22}$, while Banca di Roma and San Paolo originate from the Monte di Pietà of Rome ${ }^{23}$ and the Monte di

Pietà of Turin ${ }^{24}$, respectively. More generally, the great majority of modern Italian banks trace their origin to the Monte di Pietà that were created during the Renaissance ${ }^{25}$.

Rather than separately estimating the three relationships identified above, I first estimate by ordinary least squares (OLS) the following reduced form,

$$
\log F_{i}=\alpha J_{i}^{1500}+X_{i}^{\prime} \beta+v_{i}
$$

using both the ratio of private credit to GDP and branch density as proxies for local banking development. $X_{i}$ includes a set of geographic controls (e.g., elevation, seismicity, proximity to the sea or to a river) and of province dummies. The first two columns of Table 3 report the results. Having had a Jewish community in the city in 1500 is associated with an increase of 28 percent in the current ratio of private credit to GDP and of 16 percent in the branch density of the municipality. Thus, cities that were hosting Jewish communities in 1500 are characterized by a higher level of banking development today. This positive correlation, however, does not necessarily indicate a causal effect. In particular, it could be that the same local advantage that led the Jews to settle in a particular city is also responsible for a higher level of current credit availability. Jewish demography in 1500 was certainly influenced by the economic, institutional, cultural and geographical environment. Controlling for all of these factors is practically impossible, and the regression above cannot reject

\footnotetext{
${ }^{22}$ In 1539, the Monte di Pietà of Napoli was founded with the philanthropic purpose of providing interest-free pawn loans. Later, the Monte di Pietà opened a depository bank that was recognized with a viceregal proclamation in 1584 . In the next 50 years other seven Catholic institutions were founded in Naples: the Sacro Monte e Banco dei Poveri (1600); the Banco Ave Gratia Plena or Banco della Santissima Annunziata (1587); the Banco di Santa Maria del Popolo (1589); the Banco dello Spirito Santo (1590); the Banco di Sant' Eligio (1592); the Banco di San Giacomo e Vittoria (1597); and the Banco del Santissimo Salvatore (1640). These eight banks prospered for over two hundred years until they were merged to create the "Banco Nazionale di Napoli" in 1794 by Ferdinand IV of Bourbon.

${ }^{23}$ Banca di Roma regrouped the histories of several notable Rome-based financial houses. The oldest of these was the Monte di Pietà di Roma, founded by a papal bull in 1539 in the aftermath of the sack of Rome in 1527 and the famine of 1538 . The rebuilding effort drained the city of credit capital and increases the interest rates placed by the Jewish moneylenders. In response, Pope Paul III issued a bull establishing the Monte di Pietà di Roma, which was placed under the protection of the Franciscan Order . Another Italian bank that participated in the development of what became Banca di Roma is the Banco di Santo Spirito created in 1605 in order to raise funding for the charitable operations of the Arch-hospital Santo Spirito.

${ }^{24}$ The "Campagnia della Fede Cattolica di San Paolo" was created in 1563 after Piedmont had countered the invasion of Phillip II of Spain. The long war had aggravated an already difficult economic situation, increasing famine and poverty in the city of Torino, and the initial aim of the Compagnia was to centralize the collection and distribution of alms. Also in this case, with the formal intent of fighting Jewish moneylenders, the Compagnia created a Monte di Pietà in 1579 that has operated uninterrupted (with an exception of less than 10 years during the Napoleonic domination of Piedmont) to the present day.

${ }^{25}$ For example, Banca Monte dei Paschi di Siena was founded in 1473 as a Monte di Pietà and is today the third Italian bank by capitalization. Banca Carige is the descendant of the Monte di Pietà di Genova. Banca Carimonte, that has recently joined the Unicredit group, is the result of aggregating four ancient Monti (Ravenna, 1491; Bologna, 1473; Savignano, 1579; Cesena, 1487) with the Cassa di Risparmio di Cesena. Unibanca, was created by the subsequent merging of several Monti (Lugo, 1546; Massa Lombarda, 1572; Faenza, 1491) with the Cassa di Risparmio di Faenza, which was part of the Monte di Faenza before becoming a separate entity in 1891. Other examples of modern Italian banks that track their origins in the experience of the Monti di Pietà are: Banca del Monte di Lucca (1516), Banca Monte Parma (1488), Banca del Monte di Lombardia (from the merging of the Monti of Milano, 1483; Mantova, 1484; Cremona, 1490; Monza, 1492; Pavia, 1493 and Bergamo, 1557). Figure 4 is a picture of the main bank branch in the city of Bologna today. The ancient building still reports on the main facade the denomination "Monte di Pietà di Bologna" and the its funding year, 1473.
} 
the alternative that these factors are the ultimate source of persistence.

To address this issue, I use a difference-in-difference approach based on an historical event: the expulsion of the Jews from the lands subject to the Spanish crown between 1503 and 1541. I make two assumptions.

The first assumption is that the expulsion was exogenous, meaning that there are no unobservables that are responsible for the expulsion and that have effects on current economic outcomes. This assumption may be violated if this event reflected, for example, a more intolerant local attitude towards diversity or usury. But this is not the case. The expulsion originated from the fact that, in 1503, the king of Naples, Federico II, had died without leaving any heir to the throne. The territories of the Kingdom of Naples were therefore divided between the two strongest European monarchies: the French and the Spanish. One year later, they all fell to the Spanish crown, which had conquered two other large municipalities in Central Italy. At that point, the edict of expulsion of the Jews, that had been promulgated in Spain in 1492, was extended to these new Spanish possessions in Italy. The edict was strongly opposed by the local aristocracy ${ }^{26}$ and resulted in riots and protests in several cities. It is reasonable to conclude that the edict solely reflected the attitude of the Spanish crown toward the Jews, rather than local sentiments.

The second assumption is that those unobservables that systematically drove the Jewish communities toward certain cities and that affect local current economic development are the same between those territories that fell under the Spanish crown and those territories that did not. While Jewish communities in Central and Southern Italy trace their origin to the first century CE the Jews settled in Northern Italy much later. Therefore, it may be that the locational advantage that led the Jews to settle in some locations in the North was very different from the locational advantage that led them to settle in the South. For this reason, I will focus my analysis on Central Italy, and I will only exploit variation within provinces.

Given the two assumptions above, a useful framework for studying the effect of Jewish communities during the Italian Renaissance on actual financial development is provided by the matrix described in Table 1, which divides Italian cities along two dimensions: whether they hosted a Jewish community in 1500 or not, and whether they belonged to the Spanish territories in 1503 or not. $F$ measures the current average level of local banking development in each cell.

Table 1: Difference in difference

\begin{tabular}{l|l|ll|} 
& & \multicolumn{2}{l}{ Jewish community in 1500} \\
\cline { 3 - 4 } Spanish territories in 1503 & Yes & Yes \\
\cline { 3 - 4 } & No & $F_{00}$ & $F_{01}$ \\
\cline { 3 - 4 } & & $F_{10}$ & $F_{11}$ \\
\hline
\end{tabular}

\footnotetext{
${ }^{26}$ For example Lagumina and Lagumina (1992) reports two petitions, one drawn up and signed by high ranking officials and members of the nobility, and the other from the jurats of Palermo (elective representatives) that were addressed to the king protesting against the expulsion. See also Simonsohn (2006, p. 4739-4744) and Ingram (2009).
} 
A simple test for the magnitude of the long-term effect of hosting a Jewish community can therefore be conducted by documenting whether the difference in the current local banking development of cities that hosted Jewish communities in 1500 versus cities that did not is higher in regions where the Jews were not expelled as a consequence of the Spanish domination compared to regions where they were, or:

$$
\left(F_{11}-F_{10}\right)-\left(F_{01}-F_{00}\right)
$$

As is customary in the literature, I express the difference-in-difference results in a regression format:

$$
\log F_{i}=\gamma_{1} S_{i}+\gamma_{2} J_{i}^{1500}+\gamma_{3} J_{i}^{1500} * S_{i}+X_{i}^{\prime} \gamma+\epsilon_{1 i}
$$

where $S_{i}$ is a dummy that identifies those territories that were not under the Spanish crown (and where Jews were allowed to Stay). Columns 3-9 of Table 3 report the results. In column 3, the only controls are the usual set of geographical characteristics and the province dummies.

There are two striking results.

The first is that having a Jewish community in 1500 does not have any effect on current banking development per se (the coefficient on $J_{i}^{1500}$ is negative but not significant). In the once Spanish dominated territories, where Jews were expelled, there is no current difference in local banks between cities that used to host Jewish communities and cities that did not. So, whatever unobservable led the Jews to establish in some particular cities in 1500, that does not seem to affect the level of local banking development in these cities today. A possible concern is that Spanish domination may have prevented the development of banks altogether. However, the fact that the coefficient on $S_{i}$ is negative is suggestive that the Spanish domination did not have any persistent negative effect on local banks if not through the expulsion of the Jews. In fact, cities that were under the Spanish crown display higher credit availability today compared with cities that were not under the Spanish crown and did not host a Jewish community. So, once controlling for the Jewish expulsion, the Spanish domination had positive effects on the development of banks.

The second striking result is that the coefficient of the interaction term is statistically significant at 1 percent and is very large. Having had a Jewish community in 1500 in a municipality located outside of the Spanish territories in 1503 increases current private credit-to-GDP by 57 percent. Thus, the presence of a Jewish community in 1500, in those areas where Jews had not been expelled, has surprisingly significant long-term effects on the current local banking development of Italian municipalities.

In column 4, I run a simple placebo test to confirm that the effect of Jewish demography on current credit availability comes from the fact that the Jewish community spurred the creation of the Monti di Pietà. 
Practically, I add among the regressors a triple interaction between a dummy that identifies those cities that developed a Monte di Pietà in the first century of their activity and the variables $J_{i}^{1500}$ and $S_{i}$. This triple interaction is positive and significant while, in this specification, the interaction $J_{i}^{1500} * S_{i}$ becomes five times smaller and statistically insignificant. Thus, the presence of a Jewish community in territories that were not under the Spanish crown had effects on current credit availability only in those cities that developed a Monte.

The following columns report some robustness checks on the benchmark specification. In particular, the results are robust to the inclusion of a measure of the area of the municipality (column 5) and a dummy that identifies the regional administrative capitals (column 6). In column 7, I rerun the regression, controlling for the size of the urban population in 1300 and 1400. Cities that were larger in the Renaissance could today be more economically developed as a result of having inherited a higher level of human and social capital (see Guiso et al. (2008); Percoco (2009)). This could bias my results if the Jewish communities in the Spanish territories were concentrated in smaller or larger cities compared to the other Jewish communities. The ancient urban population is clearly an endogenous regressor in equation 5: there may be certain omitted features that affected the urban population five centuries ago and that drive credit today. However, the fact that the coefficient of the interaction term is affected very marginally by its inclusion suggests that my results are not driven by the distribution of the urban population during the Renaissance.

Another possible concern is that, despite the fact that this analysis focuses on Central Italy, the factors that led to the creation of a Jewish community were different between those territories that later fell under the Spanish crown and the other. For this reason, in column 8, I limit my analysis to the border of the Spanish possessions in 1503 (more precisely, I concentrate on the three contemporaneous regions that were divided by this border: Lazio, Abruzzi and Molise). The estimate of the coefficient on the interaction term decreases slightly while the negative effect of the presence of a Jewish community becomes significative. Thus, if anything, those features that led the Jews to choose certain cities over others are associated today with a lower level of local banking development.

Finally, in the last column, I use branch density as a measure of local banking development and, also in this case, the long-term effect of Jewish demography is practically unchanged.

In sum, the presence of a Jewish community in 1500 is associated with better current credit conditions only in those territories where Jews where not expelled as a consequence of the Spanish edict. This finding suggests that what affects current banks are not the characteristics of the cities where the Jews chose to live in 1500 but rather their continuous presence in the fifteenth and sixteenth centuries. More specifically, according to the most conservative estimates, this continuous presence is currently responsible for an increase of 48 percent in the local ratio of private credit to GDP and of 44 percent in the branch density. These estimates allow us to 
evaluate the consequences of the expulsion of the Jews from the Spanish territories on the current local banking system. In particular, how much of the current North-South gap in credit availability can be explained by this event? The answer is surprisingly high for an event that occurred over five centuries ago: 12 percent for the credit-to-GDP gap and 13.4 percent for the branch-density gap. I do not have reasonable theories to explain the remaining gap. However, it is possible (in fact, likely) that these numbers underestimate the effect of the expulsion. Probably, through temporary migration (due to the mechanism of the condotta) in the sixteenth century, the Jewish communities' positive effects spilled over into the neighboring towns, further contributing to the development of financial institutions in the Center-North.

The next step to clarify the channels through which Jewish demography has affected the current local credit markets is to estimate equation 3. This would give us an estimate of the persistence of local banking institutions.

To identify the causal effect, it is necessary to isolate a variation in the local credit markets in the Renaissance that is exogenous with respect to current local credit markets. A natural candidate for an instrument in this context is Jewish demography in 1500. I have already argued that there are historical reasons to believe that Jewish communities in 1500 fostered the development of local credit markets in the early Renaissance. It remains to be argued that Jewish demography in 1500 is uncorrelated with the error term in equation 3 (i.e. $\left.\operatorname{Cov}\left(J_{i}^{1500}, v_{3, i}\right)=0\right)$. To do this, I decompose the residual $v_{3, i}$ into three parts: $\zeta_{[-\infty ; 1500], i}, \zeta_{[1500 ; 2000], i}$ and $\varepsilon_{i}$ so that:

$$
v_{3, i}=\varepsilon_{i}+\zeta_{[1500 ; 2000], i}+\zeta_{[-\infty ; 1500], i}
$$

where $\varepsilon_{i}$ represents exogenous shocks and measurement errors in the measure of the current local credit market development of city i; $\zeta_{[-\infty ; 1500], i}$ is the set of unobserved features of city $i$ that affects current credit markets and that were already in place before 1500; and $\zeta_{[1500 ; 2000], i}$ is the set of unobserved features of city $i$ that affect current credit markets and that arose after 1500. The three sufficient conditions for the exclusion restriction to be valid are: $\operatorname{Cov}\left(J_{i}^{1500}, \varepsilon_{i}\right)=0, \operatorname{Cov}\left(J_{i}^{1500}, \zeta_{[1500 ; 2000], i}\right)=0$ and $\operatorname{Cov}\left(J_{i}^{1500}, \zeta_{[-\infty ; 1500], i}\right)=0$.

Although the first condition is valid by construction, the other two require further discussion. As a first step, let me argue that $\operatorname{Cov}\left(J_{i}^{1500}, \zeta_{[1500 ; 2000], i}\right)=0$. This assumption would be invalidated if Jewish demography in the early Renaissance has an effect on current banks that is not a consequence of its direct effect on local money-lending activities in the Renaissance. As a matter of fact, Jews have traditionally displayed a high level of literacy; moreover, historically, Jews used be employed in occupations that were particularly skillintensive (Botticini and Eckstein (2005)). It could be that either Jewish communities have persisted until now and still affect the level of human capital in their cities or that they did eventually disappear but not before 
transmitting their knowledge to the rest of the population, thereby contributing to the present level of human capital. However, both cases seem implausible. First, it is well documented that the distribution of the Jewish population in Italy in the last two centuries has completely changed and, with three notable exceptions (Rome, Florence, Venice), most of the ancient Jewish communities have disappeared or are insignificant in $\operatorname{size}^{27}$. Second, it is unlikely that Jewish communities in the Renaissance could have contributed to the cultural, institutional and economic development of their cities (if not through their effects on financial development). In fact, from the beginning of the sixteenth century through the end of the nineteenth century, Jews lived segregated from the rest of the population and derived their livelihood almost exclusively from money-lending activities. The Lateran Council forbade the Catholics from interacting with the Jews for any purpose aside from business. The Jews were forced to live in a dedicated section of the city, the ghetto, that they were not allowed to leave during the night; during the day, they were obliged to wear a distinguish badge in order to be easily recognizable by the Catholics. They were excluded from all professions (with the exception of medicine), from academia and from all public offices. The restrictions became even stronger in 1555 when the Papal Bull "Cum nimis absurdum 28 ", which forbade the Jews to own any real estate, reaffirmed the necessity to segregate Jews from the Catholic population and forbade Catholics to work for the Jews or to receive treatment from Jewish doctors. The bull remained effective until 1848 in Piedmont and 1870 in the rest of Italy.

The final step in defending the exclusion restriction is arguing that $\operatorname{Cov}\left(J_{i}^{1500}, \zeta_{[-\infty ; 1500], i}\right)=0$. This condition would be violated if there were omitted variables driving both Jewish demography in the Renaissance and current local credit markets. But we have already seen that, if there is any unobservable that is systematically correlated with the cities where the Jews lived, it seems to have had negative rather than positive effects on current local credit development. Thus, the 2SLS results may undervalue the persistence of local banks.

Having discussed the validity of my instruments, I can move to the two-stage least-squares estimates of equation 3. I limit the analysis to cities in regions that were not subject to the Spanish crown in 1503 . The results are presented in Table 4.

In column 1, the only covariates are the set of geographical characteristics and the province dummies. There are two striking results. First, there is an extraordinary persistence in the level of local banking development. The presence of a Monte di Pietà in the sixteenth century increases the current availability of credit to the

\footnotetext{
${ }^{27}$ Bonfil writes that "[Between 1815 and 1938], the structure of the Jewish community changed radically. In 1840 there existed about 70 organized communities, in 1938 only 23. [..] The distribution of the Jewish population also changed. Many small rural communities disappeared, while medium-sized urban ones suffered through migration to the large centers.". Some years later the Nazi persecutions in Italy during the Second Word War decimated the Italian Jewry. Through deportations, conversion to other religions and emigration, Italy lost in less than 5 years, almost half of its Jewish population.

${ }^{28}$ The first two lines of the bull: "Cum nimis absurdum et inconveniens existat ut iudaei, quos propria culpa perpetuae servituti submisit, sub praetextu quod pietas christiana illos receptet et eorum cohabitationem sustineat [...." can be translated in the following manner: "Since it is completely senseless and inappropriate to be in a situation where Christian piety allows the Jews (whose guilt - all of their own doing - has condemned them to eternal slavery) access to our society and even to live among us [..].
} 
private sector (in terms of GDP) by more than one hundred percent. Second, in line with equations (1) and (2) the presence of a Jewish community in 1500 is a strong predictor of the location of the Monti two centuries later. Having a Jewish community is associated with an increase in the probability of hosting a Monte di Pietà by nearly 40 percent. The qualitative results are confirmed in column 2 , where I add the estimated population in 1300 and 1400 to the regressors, even though the estimate of the persistence parameter, $\alpha_{3}$, drops by one third. In the third column, I used the presence of a Jewish pawnshop in the sixteenth century as an alternative proxy for the development of the local ancient credit markets. The estimates for $\alpha_{3}$ increases slightly.

In columns 4-6, I repeat the analysis using current branch density as dependent variable. The estimates for $\alpha_{3}$ are approximately one fifth compared to the previous columns. This seems to suggest that the presence of a Monte di Pietà increases not only the number of local banks but also their average size (as measured by the credit that they provide). Finally, in the columns 7 and 8, I limit the analysis to Central Italy. From a qualitative perspective, the results are unchanged.

In sum, there is robust empirical evidence for the long-term persistence of local banking institutions. The data analysis in this paragraph confirms that the presence of a Jewish community five centuries ago fostered current local banking development through its effect on the development of the Monti di Pietà.

\section{$5 \quad$ Effects of Local Banks on Development}

Local banking development is ultimately important insofar as it can affect economic outcomes. The objective of this paragraph is to estimate the impact of local banks on local economic development in Italian municipalities. More specifically, I intend to estimate the following equation:

$$
\log Y_{i}=\alpha_{4} \log F_{i}+X_{i}^{\prime} \beta_{Y}+v_{4, i}
$$

where $Y_{i}$ is income per capita in city i and $X_{i}$ is a set of covariates that affect economic performance. The coefficient of interest is $\alpha_{4}$, which captures the effect of increasing the availability of local credit on per capita income.

To identify the causal effect, also in this case I will use Jewish demography in 1500 as an instrument. From the previous paragraph, we know that Jewish demography had large long-term effects on Italian banks. To argue that Jewish demography in 1500 is uncorrelated with the residual in the equation above, I proceed as before and decompose $v_{4, i}$ into three parts: $\zeta_{[-\infty ; 1500], i}^{\prime}, \zeta_{[1500 ; 2000], i}^{\prime}$ and $\varepsilon_{i}^{\prime}$ so that:

$$
v_{4, i}=\varepsilon_{i}^{\prime}+\zeta_{[1500 ; 2000], i}^{\prime}+\zeta_{[-\infty ; 1500], i}^{\prime}
$$


where $\varepsilon_{i}^{\prime}$ represents exogenous shocks and measurement errors in the current economic development of city i; $\zeta_{[-\infty ; 1500], i}^{\prime}$ is the set of unobserved features of city $i$ that affect current economic development and that were already in place before 1500; and $\zeta_{[1500 ; 2000], i}^{\prime}$ is the set of unobserved features of city $i$ that affect current economic development and that arose after 1500. For the exclusion restriction to be valid, we need to assume that: $\operatorname{Cov}\left(J_{i}^{1500}, \zeta_{[1500 ; 2000], i}^{\prime}\right)=0$ and $\operatorname{Cov}\left(J_{i}^{1500}, \zeta_{[-\infty ; 1500], i}^{\prime}\right)=0$.

The first condition is reasonable because, as we have already seen, Jewish communities in 1500 could hardly have any effect on local economic development if not through the credit markets. In order to defend the second condition, I will use an analogous difference in difference strategy as in the previous paragraph. More specifically, I run a regression similar to equation 5 but using per-capita GDP as a dependent variable rather than credit availability:

$$
\log Y_{i}=\delta_{0} S_{i}+\delta_{1} J_{i}^{1500}+\delta_{2} J_{i}^{1500} * S_{i}+X_{i}^{\prime} \delta+\epsilon_{2 i}
$$

The estimates are reported in Table 5. In column 1, the only covariates are the set of geographical characteristics and province fixed effects. The coefficient on the interaction term is significant at 1 percent and very large: having a Jewish community in 1500, in a region where it was not later expelled, implies a higher income today by nearly 11 percent. Instead, the presence of a Jewish community in 1500 in a Spanish territory has an impact on per-capita income that is not significative, either economically or statistically. This evidence is robust when I include, among the controls, a measure of the area of the municipality (column 2), a dummy that identifies the regional administrative capitals (column 3) and the estimated urban population of the municipality in 1300 and 1400 (column 4). This suggests that after the inclusion of some observed geomorphological characteristics as well as a set of province fixed effects there are no other omitted variables correlated both with current per-capita GDP and with the presence of a Jewish community in the early Renaissance.

Most of the Jews were able to read and write during the Renaissance, while most other Italians were not. In order to exclude the possibility that the effects of Jewish communities on current local development are driven by human capital factors (in particular if Jews in a region from which they were expelled were less educated than Jews in a region from which they were not), in column 5, I add several proxies of human capital endowment among the controls ${ }^{29}$. These variables are clearly endogenous, but it is reassuring that their inclusion does not significantly affect the results.

In column 6, I limit the analysis to Central Italy. Surprisingly, the estimate of the coefficient of the interaction term increases threefold. This finding is likely due to the fact that the expansion of the "Monti di

\footnotetext{
${ }^{29}$ I add a polynomial function of the percentage of residents that is illiterate or that completed primary, secondary, upper secondary or tertiary education.
} 
Pietà" started in Central Italy and it was in these regions that the Franciscan preachers focused their efforts against Jewish usury. In the last column, I only consider those Italian regions crossed by the old border of the Spanish territories. Also in this case the estimates on the interaction terms are larger compared to the benchmark case.

The expulsion of the Jews from the regions under the Spanish crown can be read as an exogenous negative shock on the local banking development of these regions. One commonly made allegation is that the expulsion of the Jews was responsible for the long-term decline of the European territories under the Spanish $\operatorname{crown}^{30}$ and the beginning of the economic divergence between Northern and Southern Italy. The results above allow me to infer the extent to which the current North-South gap in economic development is explained by this shock. According to the most conservative estimates, if Jews had not been expelled by the Spanish territories, GDP would have been 7 percent higher in Southern Italy. Overall, the expulsion explains nearly 10 percent of the income gap between Northern and Southern Italy.

Having discussed the validity of my instruments, I move on to the two-stage least-squares (2SLS) estimates of equation 6. I limit the analysis to cities in regions that were not under the Spanish crown in 1503 . The results are presented in Table 6 . When simply regressing log income per capita on the log credit availability to the private sector, the estimates of $\alpha_{4}$ are positive and strongly significant: an increase in credit availability by 1 percent generates an increase in local GDP by 0.22 percent. As expected, the first-stage regression (reported in Panel B) indicates that the presence of a Jewish community in 1500 has a positive and significant effect on current credit availability. In column 2, I add province fixed effects. Surprisingly, their impact on the elasticity of interest is very low (it increases from 0.22 to 025 ).

Column 3 reports the benchmark specifications: the controls comprise the set of geographical characteristics together with the province dummies. The estimates for $\alpha_{4}$ are unchanged, and the F-test for the excluded instrument is 41.3, suggesting that these estimates do not suffer of a weak instrument problem.

In the following three columns, I repeat the exercise, using as an instrument not only the presence of a Jewish community in 1500 but also its size. More specifically, the availability of credit is treated as endogenous and modeled as follows:

$$
\log F_{i}=\xi_{1} J_{i}^{S}+\xi_{2} J_{i}^{M}+\xi_{3} J_{i}^{L}+X_{i}^{\prime} \xi+\nu_{i}
$$

where $J_{i}^{S}, J_{i}^{M}$ and $J_{i}^{L}$ indicate, respectively, the presence of a small, medium or large community in 1500 . Interesting, the first-stage regressions in Panel B shows that it is not only the presence of the Jewish community

\footnotetext{
${ }^{30}$ See for example Peri (1988, chp13) and Epstein (1992, p.337) for Sicily, Kamen (1988) for Spain and Martin (1949) for Southern Italy.
} 
that affects on the current credit-to-GDP ratio but also its size: the larger the Jewish community, the larger the current credit availability. Notice that the results of the second stage are practically unaffected, even though this specification raises a possible concern. It could be that the size of the Jewish community in 1500 reflects a locational advantage that continues to affect income today (I was only able to argue that the presence of the community does not).

Finally, in the last three columns, I use branch density instead of the credit-to-GDP ratio as a measure of local banking development. The results are surprising. The effect of banks on income appears much larger than in any other previous result: a 1 percent increase in branch density increases per-capita GDP by $0.7-1.2$ percent, depending upon the econometric specification. This finding seems to validate the view that banks affect economic performance not only through the provision of credit but also by supplying a greater variety of services.

Table 7 reports a set of robustness checks. The previous results are unchanged when controlling for the size of the municipality (columns 1 and 5) and for whether the city is capital of its region (columns 2 and 6). In columns 3 and 7, I add the populations of the city in 1300 and 1400 among the covariates. The main concern that motivates this robustness check is that the presence of a Jewish community during the Renaissance could serve as a proxy for the size of the city in this period. The estimates of the elasticities of per-capita income with respect to local banking development drop by a fourth (from 0.25 to 0.19 when using credit availability and from 1.2 to 0.9 when using branch density). Finally, in the columns 4 and 8, I limit the analysis to Central Italy: in these regions the effect of credit availability on GDP per capita is stronger. The coefficient of interest nearly doubles.

Overall, the 2SLS results indicate a significant effect of local banking development on economic performance. This effect is robust to different measures of banking development, different samples and different econometric specifications, although is greater when limiting the analysis to Central Italy.

\section{Financial Development and Technology}

The most successful explanation of the mechanisms through which well-functioning banks affect economic development has been suggested by the Shumpeterian growth literature, which stresses the importance of banks for aggregate productivity. According to this literature, financial intermediaries are able to identify the more innovative entrepreneurs and the more productive production processes and provide them with the necessary purchasing power by diverting the means of production from their previous uses. By selecting the more promising investments within a firm and across different firms, well-functioning banks are able to foster aggregate productivity, and, through this channel, economic development. 
To test the Shumpeterian hypothesis, I use a detailed dataset for Italian firms in the manufacturing sector. First, I infer the productivity of each firm in the sample as the residual of an estimated production function. Then, I compute a measure of the aggregate productivity in Italian cities aggregating the productivity of the local firms. Finally, I study how local banks affect it.

Assume that the (gross) production function in industry $\mathrm{j}$ is a Cobb-Douglas:

$$
\log Y_{f i t}=\varepsilon_{L}^{j} \log L_{f i t}+\varepsilon_{K}^{j} \log K_{f i t}+\varepsilon_{M}^{j} \log M_{f i t}+\delta_{i t}+\eta_{j t}+\alpha_{f}+\omega_{f i t}
$$

where $Y_{f i t}$ denotes the total sales of firm $\mathrm{f}$ in city i, $L_{f i t}, K_{f i t}$ and $M_{f i t}$ are the firm's production factors, $\delta_{i t}$ is a city-specific component of productivity, $\eta_{j t}$ an industry-specific common component of productivity, $\alpha_{f}$ a time-invariant firm level component and $\omega_{f i t}$ an idiosyncratic component. I have estimated equation 9 (at the 3-digit industry level) using several methodologies: OLS, Difference OLS, Olley and Pakes, Difference GMM and System GMM. The advantages and disadvantages of each choice are well known, although there is no agreement on which estimator should be used ${ }^{31}$. The results in this section are robust to these different methodologies.

Having obtained the estimates of the output elasticity to each production factor, I recover the total factor productivity of firm $\mathrm{f}, t_{f i}$, as follows:

$$
\log t_{f i} \equiv \log Y_{f i}-\widehat{\varepsilon}_{L}^{j} \log L_{f i}-\widehat{\varepsilon}_{K}^{j} \log K_{f i}-\widehat{\varepsilon}_{M}^{j} \log M_{f i}
$$

Finally, I compute a measure of the aggregate productivity of city i as a weighted average of the productivity of the firms operating within the city:

$$
\log T_{i} \equiv \sum_{f \in i} w_{f i} \log t_{f i}
$$

where the weights are $w_{f i} \equiv V A_{f} / \sum_{f \in i} V A_{f}$ and $V A_{f}$ is the value added produced by firm f. Aggregate productivity is then regressed on the two measures of local banking development according to the following equation:

$$
\log T_{i}=\alpha_{T} \log F_{i}+X_{i}^{\prime} \beta_{T}+\nu_{1, i}
$$

\footnotetext{
${ }^{31}$ One fundamental estimation problem is the endogeneity of the input variables, which are likely to be correlated both with $\alpha_{f}$ and $\omega_{f i t}$. Correlation with $\omega_{f i t}$ may reflect both simultaneity of input choices or measurement errors. Given the shortness of the panel, elimination of $\alpha_{f}$ through a within transformation is not the appropriate strategy. Differencing of (9) and application of the difference GMM estimator (Arellano and Bond (1991)) is a possibility, but appropriately lagged values of the regressors may be poor instruments if inputs are very persistent. Application of the GMM System estimator (Blundell and Bond (1998) and Blundell and Bond (2000)) is probably a better option. An alternative approach is the one proposed by Olley and Pakes (1996). This estimator addresses the simultaneity (and selection) problem by using firm investment as a proxy for unobserved productivity and requires the presence of only one unobserved state variable at the firm level and monotonicity of the investment function. A recent survey of different methodologies to estimate the production function is provided by Van-Beveren (2010).
} 
using Jewish demography in 1500 as an instrument.

The results are reported in the first two columns of Table 8. The only controls are the usual province fixed effects and the geomorphological characteristics. Local credit availability and branch density have a positive and significant effect on the aggregate productivity in Italian municipalities. Specifically, an increase in the credit-to-GDP ratio by 1 percent increases local aggregate productivity by 0.03 percent, while the same increase in branch density has a much larger effect, in the order or 0.2 percent.

Most of the theoretical literature focuses on two channels through which banks could affect firm productivity. First, banks produce ex ante information about possible investments; this implies a reallocation of capital towards more productive firms. Second, banks monitor investments ex post and exert corporate governance; this implies an average increase in firm productivity. In order to distinguish between these two channels, it is helpful to decompose productivity figures in Italian cities into two parts as suggested by Olley and Pakes (1996):

$$
\log T_{i, t}=\sum_{f \in i} \Delta \log t_{f i t} \Delta w_{f i t}+\overline{\log t_{i t}}
$$

where:

$$
\Delta \log t_{f i t} \equiv \log t_{f i t}-\overline{\log t_{f i t}} \text { and } \Delta w_{f i t} \equiv w_{f i t}-\overline{w_{i t}}
$$

and:

$$
\overline{\log t_{i t}} \equiv \sum_{f \in i} \log t_{f i t} \text { and } \overline{w_{i t}} \equiv \sum_{f \in i} w_{f i t}
$$

The first term in equation 13 represents the sample covariance between productivity and value added. The larger this covariance, the higher the share of value added that goes to more productive firms and the higher city i's productivity. The second term is the un-weighted average of firm-level productivity figures. Generally, the first term is interpreted as a measure of how efficient the economy is in reallocating the inputs towards more productive firms, while the second term is considered a valid measure of aggregate technology.

Columns 3 and 4 in Table 8 presents 2SLS estimates for the following equation:

$$
\operatorname{Re} a l l_{i}=\alpha_{R} \log F_{i}+X_{i}^{\prime} \beta_{R}+\nu_{2, i}
$$

where $\operatorname{Re} a l l_{i} \equiv \sum_{f \in i} \Delta \log t_{f i t} \Delta w_{f i t}$ and $X_{i}$ is the usual set of covariates. Local banking development has a positive and statistically significant effect on the variations in aggregate productivity that are due to the 
reallocation of resources towards more efficient firms. This finding seems to validate the original Shumpeterian view that banks exert their effects on growth by identifying the best entrepreneurs and diverting resources to finance their innovations. Ceteris paribus, a 1 percent increase in credit availability increases the reallocation term by 0.026 percent. Again, the effect of branch density is much larger given that a 1 percent increase in the latter increases the reallocation term by 0.16 percent. While the effect of local banking development on the reallocation of resources toward more productive firms is sizeable from an economic point of view and is significant, I do not find any evidence of an effect on the un-weighted average of firm productivity figures. The last two columns in Table 8 present 2SLS estimates for the following equation:

$$
\overline{\log t_{i}}=\alpha_{U} \log F_{i}+X_{i}^{\prime} \beta_{U}+\nu_{3, i}
$$

Credit availability has a small and statistically insignificant effect on the un-weighted average firm-level productivity. The effect of branch density is roughly five times larger but still statistically insignificant.

In conclusion, local banking development has strong positive effects on the city-level aggregate productivity. Moreover, the effects of banks on aggregate productivity appear to operate by reallocating resources towards more productive firms rather than by boosting the average productivity of firms. This seems to validate theories that stress the importance of the role of the banks in exploiting ex ante information on investment opportunities to select the more promising ones.

\section{Conclusion}

A significant historiography has conjectured that the Jewish communities in Italy had an important role in fostering the origin of local banks, and through this channel, the economic development of a large number of Italian cities. In particular, a fascinating hypothesis that has been presented by this literature is that the same decline of Southern Italy began with the expulsion of the Jews by the Spanish crown and its subsequent effects on the local credit markets. This conjecture, which has not been formally tested, is interesting for two reasons: it presupposes an extraordinary persistence in the level of local banking development, and it imputes to local banks a pivotal role in the development of local economies.

My results confirm that the level of local banking development during the Renaissance (proxied by the presence of a Monte di Pietà or a Jewish pawnshop) had strong causal effects on the current availability of credit in Italian municipalities. Moreover, there is evidence that local banks have had an important effect on current income. In particular, well-functioning banks are better able to reallocate resources toward the most productive firms and, in this way, boost aggregate productivity and income. Finally, my empirical estimates 
suggest that the Jewish expulsion from the Spanish territories in Italy is responsible for a significant portion of the income gap between Northern and Southern Italy.

What this work lacks is a rigorous analysis of the mechanisms that are responsible for such persistence in the level of local banking development. I can speculate that one of the primary reasons is that a bank's major asset is its reputation, which usually appreciates over time but further research is needed in this direction. Also, although I provide evidence of a particular channel through which local banks may affect income, the Shumpeterian one, other channels may be working at the same time. In particular, in two parallel works, I examine the effects of the local banking system on innovation and organized crime, again exploiting Jewish demography as an exogenous source of variation.

My findings do not imply that banking institutions today are predetermined by local historical events and cannot be changed. This paper belongs to a large empirical literature that examines the long-lasting effects of historical events and that has sometimes been criticized for being defeatist ${ }^{32}$. This is not my point of view. I emphasize Jewish demography as one of the many factors affecting Italian local financial institutions; because it is arguably exogenous, it is useful as an instrument for isolating the effects of banks on development. In fact, my reading of the results of this paper is that improvements in financial institutions may substantially benefit the economic environment.

\section{References}

Acemoglu, D., S. Johnson, and J. A. Robinson (2001). The colonial origins of comparative development: An empirical investigation. American Economic Review 91(5), 1369-1401.

Alesina, A. and E. L. Ferrara (2005). Ethnic diversity and economic performance. Journal of Economic Literature 43(3), 762-800.

Alesina, A., P. Giuliano, and N. Nunn (2011). On the origins of gender roles: Women and the plough. IZA Discussion Papers 5735, Institute for the Study of Labor (IZA).

Alessandrini, P., A. Presbitero, and A. Zazzaro (2006). Banks, distances and financing constraints for firms. Working Papers 266, Universita’ Politecnica delle Marche (I), Dipartimento di Economia.

Angelini, P. and N. Cetorelli (2003). The effects of regulatory reform on competition in the banking industry. Journal of Money, Credit and Banking 35(5), 663-84.

\footnotetext{
${ }^{32}$ For instance, The Economist (2011) dismissed the argument by Putnam(1993) and Guiso, Sapienza and Zingales (2008) that the level of social capital in Italian municipalities has been very persistent over time and originates from the types of government in the Middle Ages by arguing that "it quickly becomes defeatist. If Italy's problems really date back to the political vacuum created by the collapse of the Roman Empire [..], then perhaps it is time to give up and sip Campari soda on the Amalfi coast instead."
} 
Angiolini, H. (1978). Bernardino da feltre, i monti di pieta' e i banchi ebraici. Il pensiero politico (2), 193-214.

Arellano, M. and S. Bond (1991). Some tests of specification for panel data: Monte carlo evidence and an application to employment equations. Review of Economic Studies 58(2), 277-97.

Banfield, E. (1958). The moral basis of a backward society. The Free Press.

Beloch, K. J. (1963). Bevolkerungsgeschichte Italiens. Walter de Gruyter Press.

Bencivenga, V. R. and B. D. Smith (1991). Financial intermediation and endogenous growth. Review of Economic Studies 58(2), 195-209.

Benfratello, L., F. Schiantarelli, and A. Sembenelli (2008). Banks and innovation: Microeconometric evidence on italian firms. Journal of Financial Economics 90(2), 197-217.

Blundell, R. and S. Bond (1998). Initial conditions and moment restrictions in dynamic panel models. Journal of Econometrics 87, 115-143.

Blundell, R. and S. Bond (2000). Gmm estimation with persistent panel data: an applications to production functions. Econometric Review 87(115-143).

Bofondi, M. and G. Gobbi (2004). Bad loans and entry into local credit markets. Tema di discussione 509, Bank of Italy.

Bonaccorsi di Patti, E. and G. Dell'Ariccia (2004). Bank competition and firm creation. Journal of Money, Credit and Banking 36(2), 225-51.

Bonfil, R. (1991). Jewish life in Renaissance Italy. University of California Press.

Botticini, M. (2000). A tale of "benevolent" governments: Private credit markets, public finance, and the role of jewish lenders in medieval and renaissance italy. The Journal of Economic History 60(1), 164-189.

Botticini, M. and Z. Eckstein (2005). Jewish occupational selection: Education, restrictions, or minorities? The Journal of Economic History $65(04)$, 922-948.

Botticini, M. and Z. Eckstein (2007). From farmers to merchants, conversions and diaspora: Human capital and jewish history. Journal of the European Economic Association 5(5), 885-926.

Comin, D., W. Easterly, and E. Gong (2010). Was the wealth of nations determined in 1000 bc? American Economic Journal: Macroeconomics 2(3), 65-97. 
De Maddalena, A. (1975). Uomini e monete preindustriali: Personaggi in cerca d'autore. Rivista Storica Italiana (87), 235-244.

Diamond, D. W. (1996). Financial intermediation as delegated monitoring: a simple example. Bank of Richmond Economic Quarterly, 51-66.

Durante, R. (2009). Risk, cooperation and the economic origins of social trust: an empirical investigation. MPRA Paper 25887, University Library of Munich, Germany.

Economist, T. (2011). The wonders of commune-ism.

Engerman, S. L. and K. L. Sokoloff (1994). Factor endowments: Institutions, and differential paths of growth among new world economies: A view from economic historians of the us. NBER Working Papers 66.

Felice, E. (2005). Il valore aggiunto regionale: Una stima per il 1891 e per il 1911 e alcune elaborazioni di lungo periodo. Rivista di Storia Economica $21(3)$.

Fry, M. J. (1995). Money, interest, and banking in economic development. John Hopkins University Press.

Greenwood, J. and B. Jovanovic (1989). Financial development, growth, and the distribution of income. NBER Working Papers 3189.

Guiso, L., P. Sapienza, and L. Zingales (2004). Does local financial development matter? The Quarterly Journal of Economics 119(3), 929-969.

Guiso, L., P. Sapienza, and L. Zingales (2006). The cost of banking regulation. Technical Report 5864, CEPR Discussion Papers.

Guiso, L., P. Sapienza, and L. Zingales (2008). Long term persistence. NBER Working Papers 14278.

Ingram, K. (2009). The conversos and moriscos in late medieval spain and beyond. In Studies in Medieval and Reformation Traditions.

Jayaratne, J. and P. E. Strahan (1996). The finance-growth nexus: Evidence from bank branch deregulation. The Quarterly Journal of Economics 111(3), 639-70.

Kamen, H. (1988). The mediterranean and the expulsion of spanish jews in 1492. The Past and the Present Society 119, 39-55.

King, R. G. and R. Levine (1993a). Finance and growth: Schumpeter might be right. The Quarterly Journal of Economics 108(3), 717-37. 
King, R. G. and R. Levine (1993b). Finance, entrepreneurship and growth: Theory and evidence. Journal of Monetary Economics 32(3), 513-542.

La-Porta, R., F. Lopez-De-Silanes, A. Shleifer, and R. W. Vishny (1997). Legal determinants of external finance. American Finance Association 52(3), 1131-1150.

La-Porta, R., F. Lopez-De-Silanes, A. Shleifer, and R. W. Vishny (1998). Law and finance. Journal of Political Economy 106(6), 1113-1155.

Lagumina, B. and G. Lagumina (1992). Codice Diplomatico dei Giudei di Sicilia e Palermo: 1884-1890.

Lerner, J. (1995). Venture capitalists and the oversight of private firms. Journal of Finance 50(1), 301-18.

Levine, R. (1998). The legal environment, banks, and long-run economic growth. Journal of Money, Credit and Banking $30(3), 596-613$.

Levine, R. (1999). Law, finance, and economic growth. Journal of Financial Intermediation 8(1-2), 8-35.

Levine, R. (2005). Finance and Growth: Theory and Evidence. Elsevier.

Levine, R., N. Loayza, and T. Beck (2000). Financial intermediation and growth: Causality and causes. Journal of Monetary Economics 46(1), 31-77.

Lucchetti, R., L. Papi, and A. Zazzaro (2001). Banks' inefficiency and economic growth: A micro-macro approach. Scottish Journal of Political Economy 48(4), 400-424.

Malanima, P. (1998). Italian cities 1300-1800. Rivista di Storia Economica 2(19), 92-126.

Martin, F. R. (1949). La expulsión de los judíos del reino de nápoles. Hispania 9, 28-76; 179-240.

Menning, C. B. (1993). Charity and state in late Renaissance italy: the Monte di Pieta of Florence. Cornell University Press.

Milano, A. (1963). Storia degli Ebrei in Italia. Giulio Einaudi Editore.

Montanari, D. (Ed.) (1999). Monti di Pieta' e presenza ebraica in Italia. Bulzoni Editore.

Morelli, L. (2008). Guilds reappraised: Italy in the early modern period. International Review of Social History 53(16), 159-178.

North (1990). Institutions, Institutional Change and Economic Performance. Cambridge University Press.

North, D. (1981). Structure and Change in Economic History. Q.Q. Norton, New York. 
North, D. and R. Thomas (1973). The Rise of the Western World. Cambridge University Press.

Nunn, N. (2009). The importance of history for economic development. Annual Review of Economics 1(1), 65-92.

Nunn, N. and L. Wantchekon (2009). The slave trade and the origins of mistrust in africa. NBER Working Papers 14783, National Bureau of Economic Research, Inc.

Olley, G. S. and A. Pakes (1996). The dynamics of productivity in the telecommunications equipment industry. Econometrica 64(6), 1263-97.

Pagliazzi, P. and N. Nicosia (1968). Monte di soccorso. Novissimo Digesto Italiano 10, 889-890.

Percoco, M. (2009). History, geography and economies of agglomeration: Evidence from italian cities. mimeo.

Petersen, M. A. and R. G. Rajan (2002). Does distance still matter? the information revolution in small business lending. Journal of Finance 57(6), 2533-2570.

Placanica, A. (1982). Moneta, prestiti, usure nel Mezzogiorno moderno. Societa' Editrice Napoletana, Napoli.

Putnam, R. (1993). Making democracy work. Civic Traditions in Modern Italy. The Princeton Press.

Racine, P. (2004). Dal Monte di Pieta' alla Cassa di Risparmio: l'Esempio Piacentino. TSG.

Rajan, R. G. and L. Zingales (1998). Financial dependence and growth. American Economic Review 88(3), $559-86$.

Segre, R. (1978). Bernardino da feltre, i monti di pieta' e i banchi ebraici. Rivista Storica Italiana (90), 818-833.

Shulvass, M. A. (1973). The Jews in the world of the Renaissance. Spertus College of Judaica Press.

Spolaore, E. and R. Wacziarg (2009). The diffusion of development. The Quarterly Journal of Economics $124(2), 469-529$.

Van-Beveren, I. (2010). Total factor productivity estimation: a practical review. Journal of Economic Surveys $10,215-33$.

Zamagni, V. (2005). L'Eta' Contemporanea. Marsilio Editori. 
Table 2: Summary Statistics for the Samples Used in Estimation

\begin{tabular}{|c|c|c|c|c|c|c|}
\hline \multirow[t]{3}{*}{ PANEL A } & \multicolumn{6}{|c|}{ City level data (historical) } \\
\hline & & & Standard & & & \\
\hline & Mean & Median & Deviation & Min & $\operatorname{Max}$ & $N$ \\
\hline Small Jewish Community & 0.28 & 0.00 & 0.45 & 0.00 & 1.00 & 360 \\
\hline Medium Jewish Community & 0.13 & 0.00 & 0.34 & 0.00 & 1.00 & 360 \\
\hline Large Jewish Community & 0.07 & 0.00 & 0.25 & 0.00 & 1.00 & 360 \\
\hline Monte di Pietà (1470-1570) & 0.29 & 0.00 & 0.45 & 0.00 & 1.00 & 360 \\
\hline Jewish Pawnshop & 0.33 & 0.00 & 0.47 & 0.00 & 1.00 & 360 \\
\hline Population 1300 & 6.06 & 0.00 & 13.98 & 0.00 & 150.00 & 360 \\
\hline Population 1400 & 2.72 & 0.00 & 8.99 & 0.00 & 100.00 & 360 \\
\hline \multirow[t]{3}{*}{ PANEL B } & \multicolumn{6}{|c|}{ City level data } \\
\hline & & & Standard & & & \\
\hline & Mean & Median & Deviation & Min & $\operatorname{Max}$ & $N$ \\
\hline GDP per Capita & 17.47 & 17.48 & 6.01 & 5.58 & 36.75 & 720 \\
\hline Credit /GDP & 0.71 & 0.57 & 0.61 & 0.02 & 4.85 & 720 \\
\hline Branches /Population & 0.00051 & 0.00048 & 0.00025 & 0.00008 & 0.00128 & 720 \\
\hline Altimetry Min & 95.49 & 43.50 & 119.97 & -3.00 & 584.00 & 720 \\
\hline Altimetry Max & 644.55 & 485.50 & 559.35 & 3.00 & $2,635.00$ & 720 \\
\hline Altimetry Average & 218.37 & 144.50 & 207.67 & 0.00 & $1,049.00$ & 720 \\
\hline Seismicity & 2.61 & 2.00 & 0.96 & 1.00 & 4.00 & 720 \\
\hline Sea & 0.14 & 0.00 & 0.34 & 0.00 & 1.00 & 720 \\
\hline Close to Sea & 0.10 & 0.00 & 0.30 & 0.00 & 1.00 & 720 \\
\hline river & 0.47 & 0.00 & 0.50 & 0.00 & 1.00 & 720 \\
\hline Region Capital & 0.05 & 0.00 & 0.22 & 0.00 & 1.00 & 720 \\
\hline City Area & 126.66 & 93.00 & 128.79 & 2.00 & $1,499.00$ & 720 \\
\hline Illiterate & 0.02 & 0.02 & 0.02 & 0.00 & 0.09 & 720 \\
\hline Primary Education & 0.25 & 0.24 & 0.03 & 0.17 & 0.34 & 720 \\
\hline Secondary Education & 0.29 & 0.29 & 0.03 & 0.19 & 0.39 & 720 \\
\hline Upper-Secondary Education & 0.26 & 0.26 & 0.04 & 0.15 & 0.37 & 720 \\
\hline Tertiary Education & 0.08 & 0.07 & 0.03 & 0.03 & 0.18 & 720 \\
\hline \multirow[t]{2}{*}{ PANEL C } & \multicolumn{6}{|c|}{ Firm level data: Amadeus database } \\
\hline & Mean & Median & $\begin{array}{r}\text { Standard } \\
\text { Deviation }\end{array}$ & Min & $\operatorname{Max}$ & $N$ \\
\hline Sales & 15900 & 3530 & 99700 & 13 & 6400000 & 92316 \\
\hline Net Value of Capital & 3120 & 495 & 22500 & 1 & 2010000 & 92316 \\
\hline Wages & 2230 & 585 & 11400 & 1 & 619000 & 92316 \\
\hline Cost of Intermediates & 12200 & 2570 & 83000 & 11 & 6000000 & 92316 \\
\hline Employees & 71.03 & 24.00 & 310.94 & 1 & 18100 & 76301 \\
\hline
\end{tabular}

Note:Panel A reports statistics on historical data. The sample is limited to the towns in Italy (excluding the islands) that had a population of at least 5000 people in 1861. Historical data on urban populations are in thousands (source: Malanima (1998)). Data on the size of Jewish demography refer to 1500 A.D. (source: Milano (1963)). Data on the presence in the municipality of a Monte di Pietà or a Jewish pawnshops refer to the years 1470-1570 A.D. (source:Montanari (1991) and Meneghin (1986)). In Panel B, "GDP per Capita" is the per capita value added in the "local labor system" to which the municipality belongs, expressed in thousands of euros (source: INSTAT). "credit/GDP" is the ratio of claims on nonfinancial private sector to GDP in the municipality (source: Bank of Italy). "Branches/Population" is the ratio of the number of bank branches to residents (source: Bank of Italy). Altimetry is expressed in meters (source: ISTAT). "Sea" is a dummy that identifies cities on the sea; "Close to Sea" is a dummy that identifies cities that are less than 5 miles from the sea; "River" is a dummy that identifies cities that are crossed by a major river. "Region Capital" is a dummy variable equal to one if the city is the capital of its region (year 2002). "City Area" is the extension of the municipality in square meters (year 1991). Panel C reports statistics for the Amadeus firm-level data in the year 2005. "Sales", "Net value of capital", "Wages" are expressed in thousands of euros. 
Table 3: Jewish communities in the Renaissance and current banks

\begin{tabular}{|c|c|c|c|c|c|c|c|c|c|}
\hline & $\begin{array}{c}1) \\
\text { Credit/GDP } \\
\end{array}$ & $\begin{array}{c}(2) \\
\text { Branch Dens. }\end{array}$ & \multicolumn{6}{|c|}{ Credit/GDP } & $\begin{array}{c}(9) \\
\text { Branch Dens. }\end{array}$ \\
\hline JEW & $\begin{array}{l}0.276^{* *} \\
(0.104)\end{array}$ & $\begin{array}{l}0.159^{* *} \\
(0.0509)\end{array}$ & $\begin{array}{l}-0.199 \\
(0.229)\end{array}$ & $\begin{array}{l}-0.305 \\
(0.209)\end{array}$ & $\begin{array}{l}-0.215 \\
(0.223)\end{array}$ & $\begin{array}{l}-0.225 \\
(0.224)\end{array}$ & $\begin{array}{l}-0.250 \\
(0.225)\end{array}$ & $\begin{array}{c}-0.472^{* *} \\
(0.143)\end{array}$ & $\begin{array}{c}-0.124 \\
(0.0806)\end{array}$ \\
\hline JEW ${ }^{*} \mathrm{STAY}$ & & & $\begin{array}{c}0.576^{* *} \\
(0.275)\end{array}$ & $\begin{array}{c}0.139 \\
(0.260)\end{array}$ & $\begin{array}{c}0.533^{* *} \\
(0.265)\end{array}$ & $\begin{array}{c}0.554^{* *} \\
(0.269)\end{array}$ & $\begin{array}{l}0.481^{*} \\
(0.268)\end{array}$ & $\begin{array}{l}0.494^{*} \\
(0.264)\end{array}$ & $\begin{array}{c}0.442^{* *} \\
(0.101)\end{array}$ \\
\hline $\mathrm{JEW}^{*} \mathrm{STAY}^{* \mathrm{M}}$ & & & & $\begin{array}{c}0.689^{* * *} \\
(0.0882)\end{array}$ & & & & & \\
\hline STAY & & & $\begin{array}{c}-0.436^{*} \\
(0.242)\end{array}$ & $\begin{array}{l}-0.142 \\
(0.216)\end{array}$ & $\begin{array}{c}-0.452^{*} \\
(0.236)\end{array}$ & $\begin{array}{c}-0.427^{*} \\
(0.243)\end{array}$ & $\begin{array}{l}-0.362 \\
(0.241)\end{array}$ & $\begin{array}{l}-0.118 \\
(0.237)\end{array}$ & $\begin{array}{c}-0.332^{* *} \\
(0.109)\end{array}$ \\
\hline AREA & & & & & $\begin{array}{c}0.0009^{* *} \\
(0.0002)\end{array}$ & & & & \\
\hline CAPITAL & & & & & & $\begin{array}{c}0.609^{* *} \\
(0.066)\end{array}$ & & & \\
\hline POP1300 & & & & & & & $\begin{array}{r}-0.0001 \\
(0.005)\end{array}$ & & \\
\hline POP1400 & & & & & & & $\begin{array}{c}0.0305^{* *} \\
(0.008)\end{array}$ & & \\
\hline GEOGRAPHY & YES & YES & YES & YES & YES & YES & YES & YES & YES \\
\hline YEAR DUM. & YES & YES & YES & YES & YES & YES & YES & YES & YES \\
\hline PROV. DUM. & YES & YES & YES & YES & YES & YES & YES & YES & YES \\
\hline $\mathrm{r} 2$ & 0.322 & 0.241 & 0.347 & 0.490 & 0.418 & 0.406 & 0.449 & 0.468 & 0.557 \\
\hline $\mathrm{N}$ & 154 & 160 & 154 & 154 & 154 & 154 & 154 & 80 & 84 \\
\hline Sample & & & Centra & taly & & & & Lazio, & uzzo, Molise \\
\hline
\end{tabular}

The table reports OLS estimates for the years 2002-2003. The unit of observation is the municipality. The left hand side variables are Credit/GDP, the log ratio of claims on nonfinancial private sector to GDP in the municipality and Branch Density, the log ratio of the number of bank branches over total residents in the municipality. JEW is a dummy variable equal to one if the municipality hosted a Jewish community in 1500 A.D. STAY is a dummy equal to one if the municipality was not under the Spanish crown in $1500 \mathrm{AD} . \mathrm{M}$ is a dummy variable equal to one if the municipality hosted a Monte di Pietà in the years 1470-1570 AD. AREA is the extension of the municipality in square meters (data refers to 1991). CAPITAL is a dummy variable equal to one if the city is the capital of the region. POP1300 and POP1400 are the estimated urban population in the municipality in 1300 AD and 1400 AD. The set of PROVINCE DUMMIES refers to the Italian provinces in 1992. Geographical variables are elevation of the municipality (minimum, maximum, average), seismicity (as reported by the Italian national statistical institute) and three dummies for whether the city is located on the coast or close to the cost (less than 5 miles distant) or on a river. Standard errors (reported in parentheses) are two-way clustered (municipality and year). ${ }^{* * *}$ significant at less than 1 percent; ${ }^{* *}$ significant at 5 percent; ${ }^{*}$ significant at 10 percent. 
Table 4: Long-term persistency of local financial institutions

\begin{tabular}{|c|c|c|c|c|c|c|c|c|}
\hline PANEL A & \multicolumn{3}{|c|}{ Credit/GDP } & (4) & $\begin{array}{c}5) \\
\text { anch Dens }\end{array}$ & (6) & $\begin{array}{c}(7) \\
\text { Credit/GDP } \\
\end{array}$ & $\begin{array}{c}(8) \\
\text { Branch Density } \\
\end{array}$ \\
\hline Monte di Pietà & $\begin{array}{c}1.250^{* * *} \\
(0.199)\end{array}$ & $\begin{array}{c}0.828^{* * * *} \\
(0.187)\end{array}$ & & $\begin{array}{c}0.281^{* * *} \\
(0.0755)\end{array}$ & $\begin{array}{c}0.240^{* * *} \\
(0.0834)\end{array}$ & & $\begin{array}{c}1.480^{* * *} \\
(0.438)\end{array}$ & $\begin{array}{c}0.489^{* * *} \\
(0.179)\end{array}$ \\
\hline Jewish Pawnshop & & & $\begin{array}{c}1.460^{* * *} \\
(0.282)\end{array}$ & & & $\begin{array}{c}0.343^{* * *} \\
(0.101)\end{array}$ & & \\
\hline POP1300 & & $\begin{array}{l}-0.00534 \\
(0.00566)\end{array}$ & & & $\begin{array}{l}-0.00128 \\
(0.00263)\end{array}$ & & & \\
\hline POP1400 & & $\begin{array}{c}0.0191^{* *} \\
(0.00769) \\
\end{array}$ & & & $\begin{array}{c}0.00302 \\
(0.00360) \\
\end{array}$ & & & \\
\hline GEOGRAPHY & YES & YES & YES & YES & YES & YES & YES & YES \\
\hline PROV. DUM. & YES & YES & YES & YES & YES & YES & YES & YES \\
\hline YEAR DUM. & YES & YES & YES & YES & YES & YES & YES & YES \\
\hline archi2p & $4.13 \mathrm{e}-13$ & $5.18 \mathrm{e}-6$ & $4.13 \mathrm{e}-13$ & $1.54 \mathrm{e}-5$ & $8.81 \mathrm{e}-6$ & $8.81 \mathrm{e}-6$ & $2.73 \mathrm{e}-3$ & $1.35 \mathrm{e}-3$ \\
\hline $\mathrm{F}$ & 42.39 & 38.07 & 34.88 & 48.70 & 43.55 & 36.65 & 10.59 & 14.90 \\
\hline $\mathrm{N}$ & 336 & 336 & 340 & 340 & 340 & 340 & 138 & 142 \\
\hline SAMPLE & & $\begin{array}{r}\text { All Ita } \\
\text { the Spa }\end{array}$ & $\begin{array}{l}\text { lian cities } \\
\text { lish crown }\end{array}$ & $\begin{array}{l}\text { inder } \\
500 \mathrm{AD}\end{array}$ & & & $\begin{array}{r}\text { Cities in Cer } \\
\text { the Spanisl }\end{array}$ & $\begin{array}{l}\text { Italy not under } \\
\text { wn in } 1500 \mathrm{AD}\end{array}$ \\
\hline \multicolumn{9}{|l|}{ PANEL B } \\
\hline JEW & $\begin{array}{l}0.362 * * \\
(0.0460)\end{array}$ & $\begin{array}{l}0.354^{* *} \\
(0.0475)\end{array}$ & $\begin{array}{l}0.296^{* *} \\
(0.0434)\end{array}$ & $\begin{array}{l}0.362^{* *} \\
(0.0460)\end{array}$ & $\begin{array}{l}0.354^{* *} \\
(0.0475)\end{array}$ & $\begin{array}{l}0.296^{* *} \\
(0.0434)\end{array}$ & $\begin{array}{l}0.334^{* *} \\
(0.0771)\end{array}$ & $\begin{array}{l}0.334^{* *} \\
(0.0771)\end{array}$ \\
\hline $\mathrm{r} 2$ & 0.176 & 0.285 & 0.203 & 0.176 & 0.285 & 0.203 & 0.214 & 0.214 \\
\hline
\end{tabular}

The table 2SLS estimates for the years 2002-2003. The unit of observation is the municipality. The sample is limited to municipalities that were not under the Spanish crown in 1503 A.D. Panel A reports the second stage estimates. The left hand side variables are Credit/GDP, the log ratio of claims on nonfinancial private sector to GDP in the municipality, and Branch Density, the log ratio of the number of bank branches over total residents in the municipality. Monte di Pietà is a dummy variable equal to one if the municipality hosted a Monte di Pietà between in the years 1470-1570 A.D. The set of PROVINCE DUMMIES refers to the Italian provinces in 1992. Geographical variables are elevation of the municipality (minimum, maximum, average), seismicity (as reported by the Italian national statistical institute) and three dummies for whether the city is located on the coast or close to the cost (less than 5 miles distant) or on a river. Archi2p reports the p-value of the Anderson-Rubin test (the null hypothesis is that the coefficients of the excluded instruments are jointly equal to zero). F is the F statistics for weak identification. Panel B reports the first stage estimates. To save space only the coefficients on excluded instruments are reported. JEW is a dummy that identifies those municipalities that hosted any kind of Jewish community in 1500 AD. Standard errors are reported in parentheses. *** significant at less than 1 percent; ${ }^{* *}$ significant at 5 percent; * significant at 10 percent. 
Table 5: Jewish communities in the Renaissance and current economic development

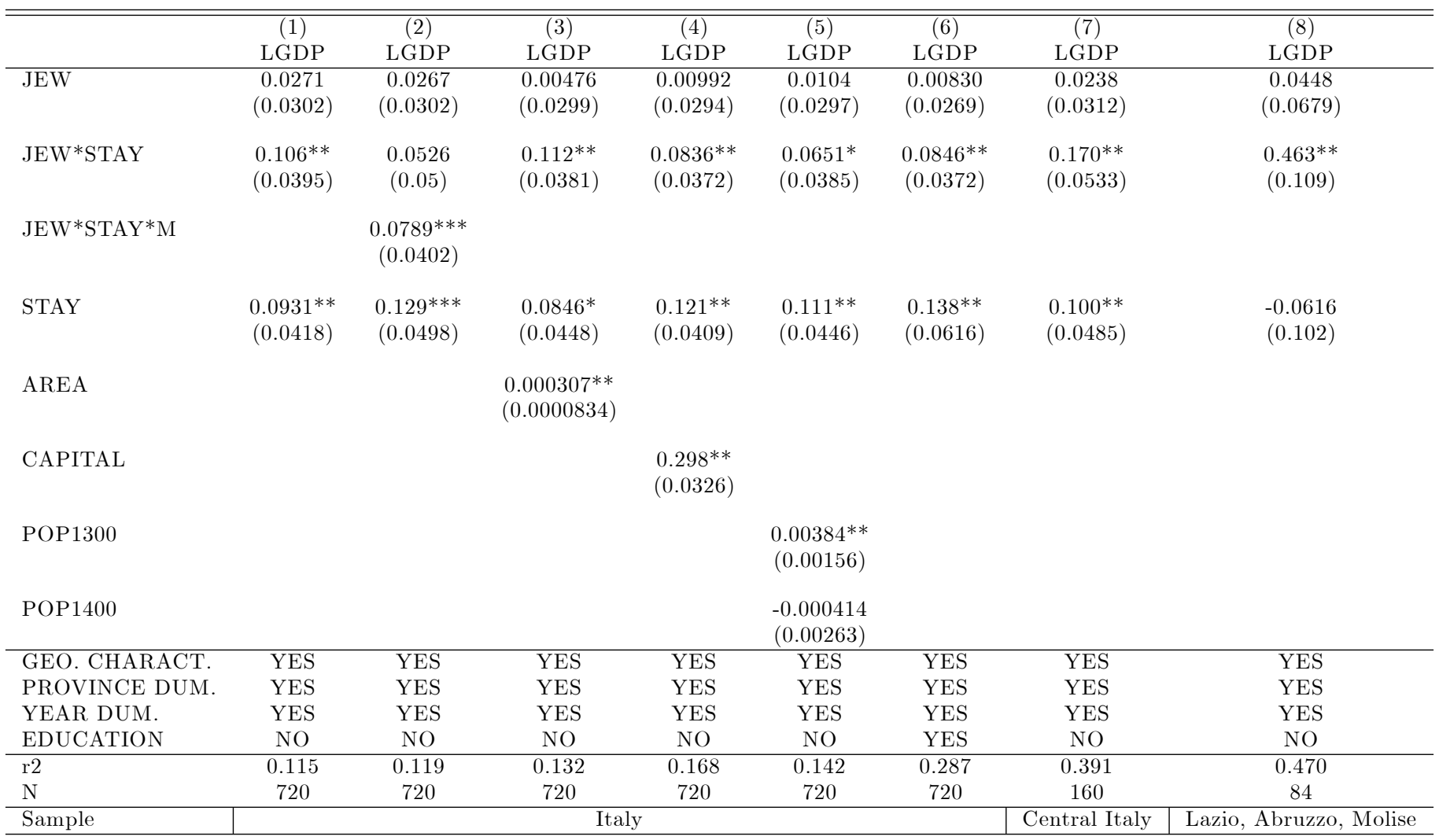

The table reports OLS estimates for the years 2002-2003. The unit of observation is the municipality. The left hand side variable, LGDP is the log of GDP per capita in the "local labor system" to which the municipality belongs.. JEW is a dummy variable equal to one if the municipality hosted a Jewish community in 1500 A.D. STAY is a dummy equal to one if the municipality was not under the Spanish crown in $1503 \mathrm{AD}$. M is a dummy variable equal to one if the municipality hosted a Monte di Pietà between in the years 1470-1570 AD. AREA is the extension of the municipality in square meters (data refers to 1991). CAPITAL is a dummy variable equal to one if the city is the capital of the region. POP1300 and POP1400 are the estimated urban population in the municipality in 1300 A.D. and 1400 A.D. The set of PROVINCE DUMMIES refers to the Italian provinces in 1992. Geographical variables are elevation of the municipality (minimum, maximum, average), seismicity (as reported by the Italian national statistical institute) and three dummies for whether the city is located on the coast or close to the cost (less than 5 miles distant) or on a river. Controls for education are the illiteracy rate, the percentage of residents that completed primary, secondary and undergraduate education. Standard errors (reported in parentheses) are two-way clustered (municipality and year). $* * *$ significant at less than 1 percent; ${ }^{*}$ significant at 5 percent; ${ }^{*}$ significant at 10 percent. 
Table 6: Banks and local economic development

\begin{tabular}{|c|c|c|c|c|c|c|c|c|c|}
\hline PANEL A & $\begin{array}{c}(1) \\
\text { LGDP }\end{array}$ & $\begin{array}{c}(2) \\
\text { LGDP }\end{array}$ & $\begin{array}{c}(3) \\
\text { LGDP }\end{array}$ & $\begin{array}{c}(4) \\
\text { LGDP }\end{array}$ & $\begin{array}{c}(5) \\
\text { LGDP }\end{array}$ & $\begin{array}{c}(6) \\
\text { LGDP }\end{array}$ & $\begin{array}{c}(7) \\
\text { LGDP }\end{array}$ & $\begin{array}{c}(8) \\
\text { LGDP }\end{array}$ & $\begin{array}{c}(9) \\
\text { LGPD }\end{array}$ \\
\hline Credit/GDP & $\begin{array}{c}0.223^{* * *} \\
(0.0782)\end{array}$ & $\begin{array}{c}0.256^{* * *} \\
(0.0698)\end{array}$ & $\begin{array}{c}0.251^{* * *} \\
(0.0616)\end{array}$ & $\begin{array}{c}0.256^{* * *} \\
(0.0546)\end{array}$ & $\begin{array}{c}0.259^{* * *} \\
(0.0537)\end{array}$ & $\begin{array}{c}0.262^{* * *} \\
(0.0518)\end{array}$ & & & \\
\hline Branch Density & & & & & & & $\begin{array}{c}0.680^{* * *} * \\
(0.251)\end{array}$ & $\begin{array}{c}1.254^{* * *} \\
(0.431)\end{array}$ & $\begin{array}{c}1.236^{* * *} \\
(0.381)\end{array}$ \\
\hline GEOGRAPHY & $\mathrm{NO}$ & $\mathrm{NO}$ & YES & $\mathrm{NO}$ & $\mathrm{NO}$ & YES & $\mathrm{NO}$ & $\mathrm{NO}$ & YES \\
\hline PROV. DUM. & $\mathrm{NO}$ & YES & YES & $\mathrm{NO}$ & YES & YES & $\mathrm{NO}$ & YES & YES \\
\hline YEAR DUM. & YES & YES & YES & YES & YES & YES & YES & YES & YES \\
\hline $\begin{array}{l}\text { archi2p } \\
\text { sarganp }\end{array}$ & $3.19 \mathrm{e}-3$ & $4.41 \mathrm{e}-6$ & $2.48 \mathrm{e}-7$ & $\begin{array}{c}6.07 \mathrm{e}-7 \\
0.161\end{array}$ & $\begin{array}{c}2.03 \mathrm{e}-9 \\
0.258\end{array}$ & $\begin{array}{c}3.19 \mathrm{e}-10 \\
0.519\end{array}$ & $1.39 \mathrm{e}-3$ & $6.47 \mathrm{e}-7$ & $2.90 \mathrm{e}-9$ \\
\hline $\mathrm{F}$ & 18.16 & 33.16 & 41.31 & 14.32 & 20.40 & 21.53 & 8.990 & 9.354 & 12.12 \\
\hline $\mathrm{N}$ & 336 & 336 & 336 & 336 & 336 & 336 & 340 & 340 & 340 \\
\hline SAMPLE & & & All Ital & $\mathrm{n}$ cities $\mathrm{n}$ & under Spa & sh crown & $1500 \mathrm{AD}$ & & \\
\hline
\end{tabular}

\begin{tabular}{|c|c|c|c|c|c|c|c|c|c|}
\hline PANEL B & & & & & & & & & \\
\hline JEW & $\begin{array}{c}0.292^{* * *} \\
(0.0682)\end{array}$ & $\begin{array}{c}0.385^{* * *} \\
(0.0600)\end{array}$ & $\begin{array}{c}0.437^{* * *} \\
(0.0603)\end{array}$ & & & & $\begin{array}{c}0.109^{* * *} \\
(0.0363)\end{array}$ & $\begin{array}{c}0.0889^{* * *} \\
(0.0261)\end{array}$ & $\begin{array}{c}0.102^{* * *} \\
(0.0259)\end{array}$ \\
\hline JEWsmall & & & & $\begin{array}{c}0.143^{*} \\
(0.0736)\end{array}$ & $\begin{array}{c}0.244^{* * *} \\
(0.0631)\end{array}$ & $\begin{array}{c}0.286 * * * \\
(0.0662)\end{array}$ & & & \\
\hline JEWmedium & & & & $\begin{array}{c}0.435 * * * \\
(0.0952)\end{array}$ & $\begin{array}{c}0.549^{* * *} * \\
(0.0798)\end{array}$ & $\begin{array}{c}0.566^{* * *} \\
(0.0782)\end{array}$ & & & \\
\hline JEWlarge & & & & $\begin{array}{c}0.686^{* * *} \\
(0.122)\end{array}$ & $\begin{array}{c}0.729^{* * *} * \\
(0.104)\end{array}$ & $\begin{array}{c}0.729^{* * *} \\
(0.101)\end{array}$ & & & \\
\hline $\mathrm{r} 2$ & 0.0517 & 0.109 & 0.199 & 0.115 & 0.185 & 0.257 & 0.0260 & 0.0329 & 0.126 \\
\hline
\end{tabular}

The table 2SLS estimates for the years 2002-2003. The unit of observation is the municipality. The sample is limited to municipalities that were not under the Spanish crown in 1503 A.D. Panel A reports the second stage estimates. The left hand side variable, LGDP is the log of GDP per capita in the "local labor system" to which the municipality belongs. Credit/GDP is the log ratio of claims on nonfinancial private sector to GDP in the municipality while Branch Density is the log ratio of the number of bank branches over total residents in the municipality. The set of PROVINCE DUMMIES refers to the Italian provinces in 1992. Geographical variables are elevation of the municipality (minimum, maximum, average), seismicity (as reported by the Italian national statistical institute) and three dummies for whether the city is located on the coast or close to the cost (less than 5 miles distant) or on a river. Sarganp reports the p-value of the Hansen-Sargan overidentification test. Archi2p reports the p-value of the Anderson-Rubin test (the null hypothesis is that the coefficients of the excluded instruments are jointly equal to zero). $\mathrm{F}$ is the $\mathrm{F}$ statistics for weak identification. Panel B reports the first stage estimates. To save space only the coefficients on excluded instruments are reported. JEW is a dummy that identifies those municipalities that hosted any kind of Jewish community in 1500 A.D. JEW small, JEWmedium and JEWlarge are dummy variables equal to one if the municipality hosted respectively a small, a medium or a large Jewish community in 1500 A.D. Standard errors are reported in parentheses. ${ }^{* * *}$ significant at less than 1 percent; ** significant at 5 percent; ${ }^{*}$ significant at 10 percent. 
Table 7: Banks and local economic development (Robustness checks)

\begin{tabular}{|c|c|c|c|c|c|c|c|c|}
\hline & $\begin{array}{c}(1) \\
\text { LGDP }\end{array}$ & $\begin{array}{c}(2) \\
\text { LGDP }\end{array}$ & $\begin{array}{c}(3) \\
\text { LGDP }\end{array}$ & $\begin{array}{c}(5) \\
\text { LGDP }\end{array}$ & $\begin{array}{c}(6) \\
\text { LGDP }\end{array}$ & $\begin{array}{c}(7) \\
\text { LGDP }\end{array}$ & $\begin{array}{c}(4) \\
\text { LGDP }\end{array}$ & $\begin{array}{c}(8) \\
\text { LGDP }\end{array}$ \\
\hline Credit/GDP & $\begin{array}{l}0.244^{* * *} \\
(0.0719)\end{array}$ & $\begin{array}{c}0.211^{* * *} \\
(0.0730)\end{array}$ & $\begin{array}{l}0.188^{* *} \\
(0.0957)\end{array}$ & & & & $\begin{array}{c}0.366^{* * *} \\
(0.118)\end{array}$ & \\
\hline Branch Density & & & & $\begin{array}{c}1.158^{* * *} \\
(0.435)\end{array}$ & $\begin{array}{c}1.050^{* *} \\
(0.409)\end{array}$ & $\begin{array}{c}0.860^{* *} \\
(0.400)\end{array}$ & & $\begin{array}{c}1.194^{* * *} \\
(0.411)\end{array}$ \\
\hline AREA & $\begin{array}{l}0.0000466 \\
(0.000121)\end{array}$ & & & $\begin{array}{c}0.000104 \\
(0.000160)\end{array}$ & & & & \\
\hline CAPITAL & & $\begin{array}{c}0.124^{*} \\
(0.0690)\end{array}$ & & & $\begin{array}{c}0.134 \\
(0.0855)\end{array}$ & & & \\
\hline POP1300 & & & $\begin{array}{l}0.000940 \\
(0.00209)\end{array}$ & & & $\begin{array}{l}0.000204 \\
(0.00272)\end{array}$ & & \\
\hline POP1400 & & & $\begin{array}{l}0.000876 \\
(0.00271)\end{array}$ & & & $\begin{array}{c}0.00287 \\
(0.00363) \\
\end{array}$ & & \\
\hline GEOGRAPHY & YES & YES & YES & YES & YES & YES & YES & NO \\
\hline PROV. DUM. & YES & YES & YES & YES & YES & YES & YES & YES \\
\hline YEAR DUM. & YES & YES & YES & YES & YES & YES & YES & YES \\
\hline $\mathrm{N}$ & 336 & 336 & 336 & 340 & 340 & 340 & 138 & 142 \\
\hline SAMPLE & \multicolumn{6}{|c|}{$\begin{array}{l}\text { All Italian Cities not under } \\
\text { the Spanish crown in } 1500 \mathrm{AD}\end{array}$} & \multicolumn{2}{|c|}{$\begin{array}{l}\text { Cities in Central Italy not under } \\
\text { the Spanish crown in } 1500 \mathrm{AD}\end{array}$} \\
\hline
\end{tabular}

The table 2SLS estimates for the years 2002-2003. The unit of observation is the municipality. The sample is limited to municipalities that were not under the Spanish crown in 1503 A.D. Panel A reports the second stage estimates. The left hand side variable, LGDP is the log of GDP per capita in the "local labor system" to which the municipality belongs. Credit/GDP is the log ratio of claims on nonfinancial private sector to GDP in the municipality while Branch Density is the log ratio of the number of bank branches over total residents in the municipality. AREA is the extension of the municipality in square meters (data refers to 1991). CAPITAL is a dummy variable equal to one if the city is the capital of the region. POP1300 and POP1400 are the estimated urban population in the municipality in 1300 A.D. and 1400 A.D. The set of PROVINCE DUMMIES refers to the Italian provinces in 1992. Geographical variables are elevation of the municipality (minimum, maximum, average), seismicity (as reported by the Italian national statistical institute) and three dummies for whether the city is located on the coast or close to the cost (less than 5 miles distant) or on a river. Sarganp reports the p-value of the Hansen-Sargan overidentification test. Archi2p reports the p-value of the Anderson-Rubin test (the null hypothesis is that the coefficients of the excluded instruments are jointly equal to zero). $\mathrm{F}$ is the $\mathrm{F}$ statistics for weak identification. Panel B reports the first stage estimates. To save space only the coefficients on excluded instruments are reported. JEW is a dummy that identifies those municipalities that hosted any kind of Jewish community in 1500 A.D. Standard errors are reported in parentheses. ${ }^{* * *}$ significant at less than 1 percent; ${ }^{* *}$ significant at 5 percent; ${ }^{*}$ significant at 10 percent.

Table 8: Banks and local aggregate productivity

\begin{tabular}{lcccccc}
\hline \hline & $(1)$ & $(2)$ & $(3)$ & $(4)$ & $(5)$ & $(6)$ \\
& LTFP & LTFP & REALLOC & REALLOC & TECHNL & TECHNL \\
\hline Credit/GDP & $0.0319^{* *}$ & & $0.0258^{* *}$ & & 0.00610 & \\
& $(0.0133)$ & & $(0.0108)$ & & $(0.00710)$ & \\
Branch Density & & $0.200^{* *}$ & & $0.162^{* *}$ & & 0.0383 \\
& & $(0.100)$ & & $(0.0776)$ & & $(0.0474)$ \\
\hline GEO. CHARACT. & YES & YES & YES & YES & YES & YES \\
PROVINCE DUM. & YES & YES & YES & YES & YES & YES \\
YEAR DUM. & YES & YES & YES & YES & YES & YES \\
\hline N & 202 & 202 & 202 & 202 & 202 & 202 \\
SAMPLE & & Italian cities not under Spanish crown in 1500AD & \\
\hline
\end{tabular}

The table reports 2SLS estimates for the years 2000-2001. The unit of observation is the municipality. The sample is limited to municipalities that were not under the Spanish crown in 1503 A.D. LTFP is a measure of aggregate productivity in the Local Labor System (LLS) to which the municipality belongs. It is computed as the weighted average productivity of the firms operating in the LLS, using as weights their shares of total value added. TECHN is the unweighted average of the productivities of the the firms operating in the Local Labor System (LLS) to which the munipality belongs. REALLOC is the difference between LTFP and REALLOC. Credit/GDP, the log ratio of claims on nonfinancial private sector to GDP in the municipality and Branch Density, the log ratio of the number of bank branches over total residents in the municipality. The set of PROVINCE DUMMIES refers to the Italian provinces in 1992. Geographical variables are elevation of the municipality (minimum, maximum, average), seismicity (as reported by the Italian national statistical institute) and three dummies for whether the city is located on the coast or close to the cost (less than 5 miles distant) or on a river. The excluded instrument is a dummy variable that identifies those municipalities that were hosting respectively a Jewish community in 1500 A.D. Standard errors (reported in parentheses) are two-way clustered (municipality and year). ${ }^{* * *}$ significant at less than 1 percent; ${ }^{* *}$ significant at 5 percent; ${ }^{*}$ significant at 10 percent. 


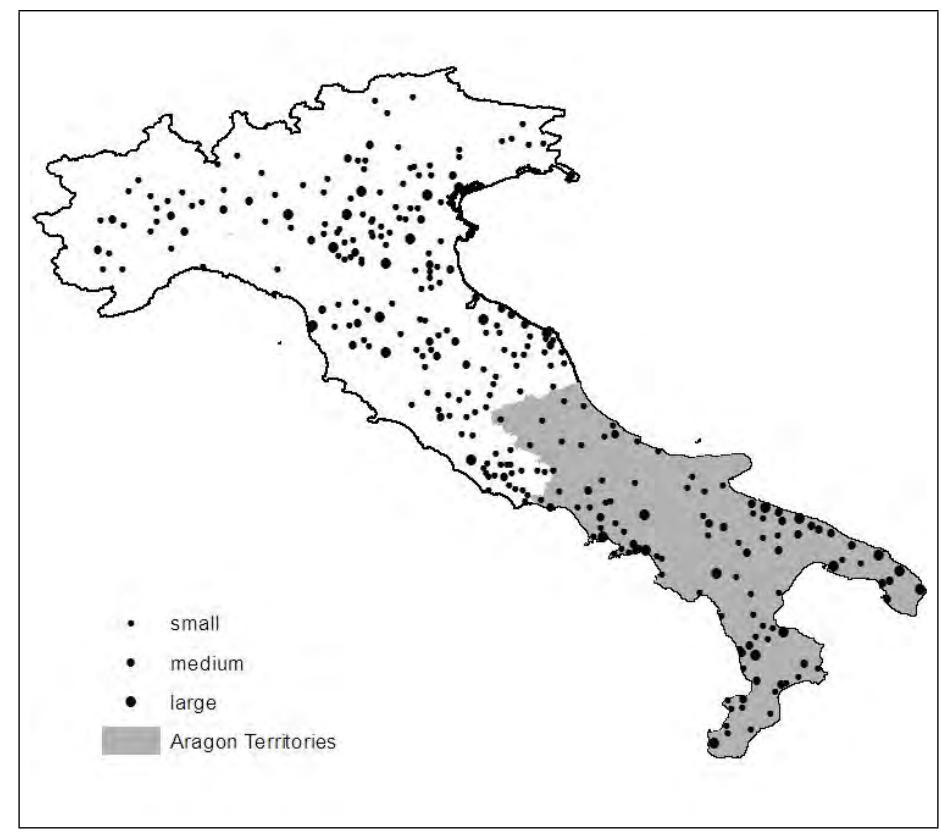

Figure 1: Jewish Communities in 1500 A.D. (excluding the islands)

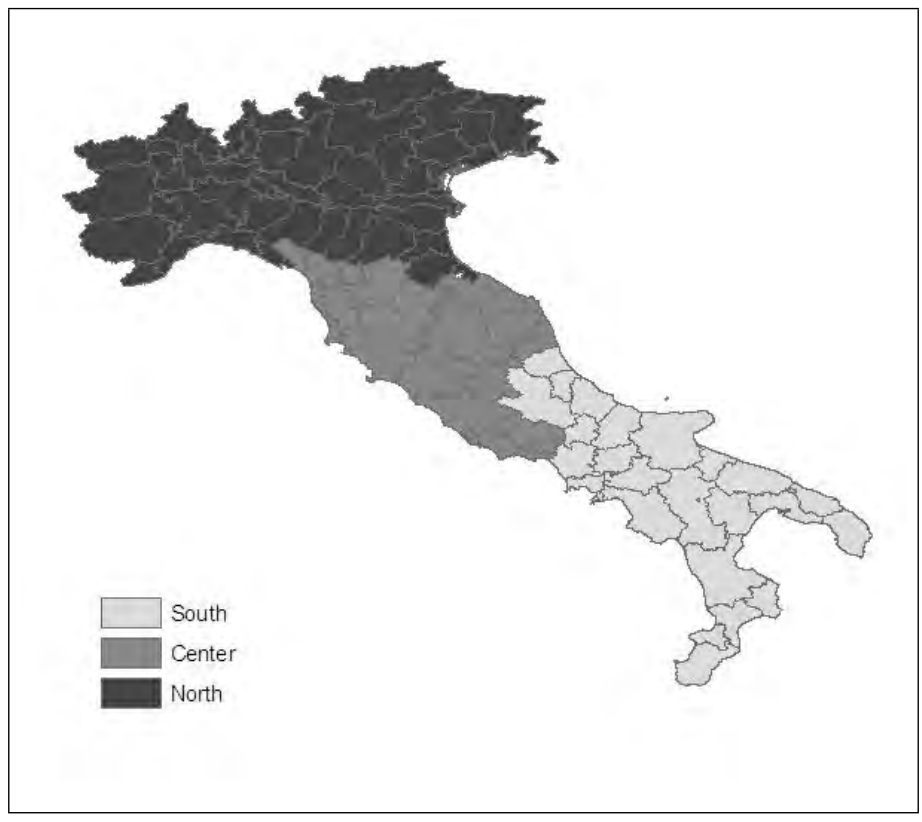

Figure 2: Italian Provinces and Macro-Regions (excluding the islands) 


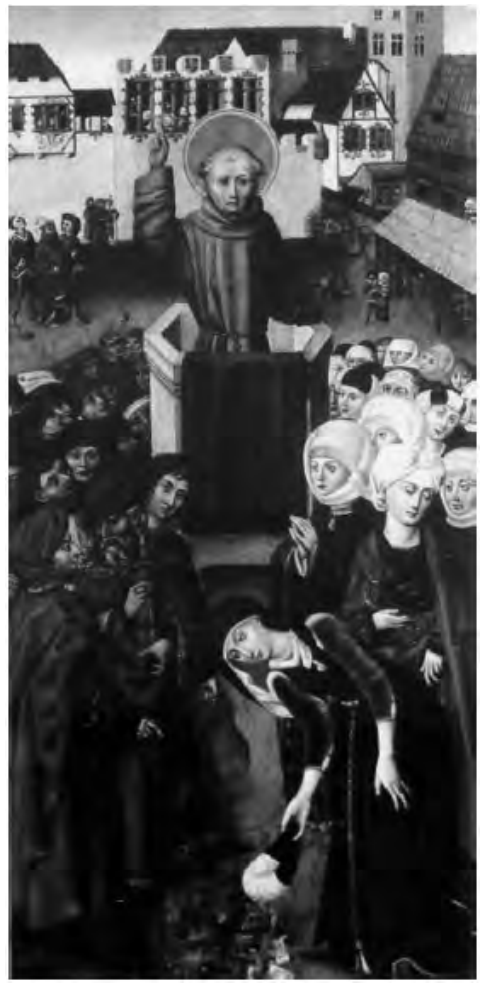

Figure 3: The sermon of Saint Giovanni da Capestrano, Historisches Museum.

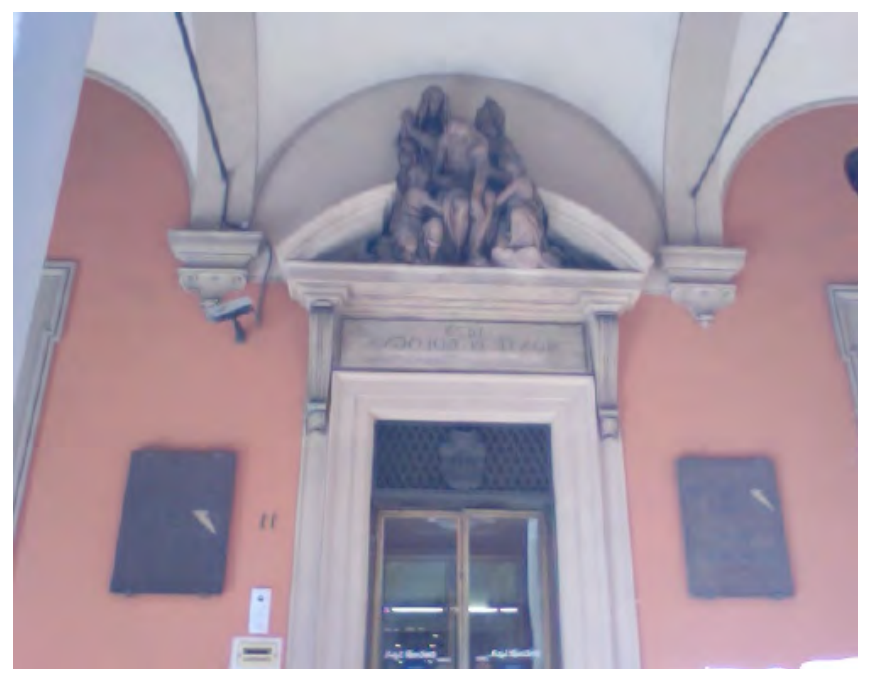

Figure 4: Monte di Pietà di Bologna 